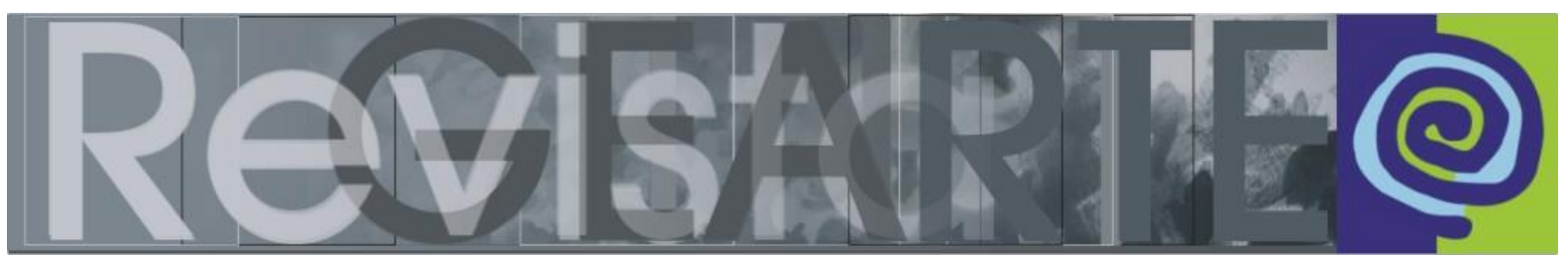

ISSN 2357-9854 | e-ISSN 2596-3198 (online)

\title{
Habitar o dissenso, germinar alegria
}

\author{
Gustavo Torrezan (i) \\ (Centro de Pesquisa e Formação do Sesc São Paulo - SESCSP, \\ São Paulo/SP, Brasil)
}

\begin{abstract}
RESUMO - Habitar o dissenso, germinar alegria - Este artigo apresenta o trabalho artístico "Convenção Mundial dos Países Imaginários", realizado durante uma residência artística na cidade de Nova Lima, Minas Gerais, na Escola Benvinda, que acolheu parte dos estudantes deslocados devido ao crime ambiental ocorrido na cidade de Brumadinho a partir do rompimento da barragem de minério da mineradora Vale do Rio Doce. Trabalhei nessa escola com a turma do terceiro ano do ensino fundamental, na classe da professora Marcia Costa, por aproximadamente um mês. O projeto se deu a partir de uma série de encontros nos quais se buscou a fabulação de uma convenção mundial de países imaginários - mote para se debater conflitos já existentes e para estimular a imaginação de outros possíveis futuros. Partindo dessas premissas, os estudantes participantes tornaram-se responsáveis por elaborar e representar seu respectivo país imaginário bem como sua cultura, escrita, idioma, bandeira, indumentárias, códigos, vozes, valores, desejos, entre outros, colocando-se como protagonistas em um processo de concepção de políticas alternativas para a construção de um novo mundo. Assim, com o intuito de reforçar o papel social da aula como um encontro acontecimental e a valorização da criança enquanto sujeito propositor e criador, o trabalho utilizou a fabulação como um mecanismo para testar procedimentos de negociação e para estimular modos de convívio e de contato a partir do dissenso.
\end{abstract}

\section{PALAVRAS-CHAVE}

Processo de criação. Fabulação. Dissenso. Cooperação. Imaginação Política.

\begin{abstract}
Dwelling dissent, germinating joy - This article presents the artistic work "World Convention of Imaginary Countries" carried out during an artistic residency in the city of Nova Lima, Minas Gerais, at Escola Benvinda, which welcomed part of the students displaced due to the environmental crime that occurred in the city of Brumadinho from the ore dam of mining company Vale do Rio Doce. I worked in this school with the class of the third year of elementary school, in the class of teacher Marcia Costa for approximately one month. The project took place from a series of meetings, in which the fable of a world convention of imaginary countries was sought, a motto to debate already existing conflicts and to stimulate the imagination of other possible futures. Based on these premises, the participating students became responsible for elaborating and representing their respective imaginary countries, as well as their culture, writing, language, flag, costumes, codes, voices, values, desires, among others, placing themselves as protagonists in a process of designing alternative policies for the construction of a new world. Thus, in order to reinforce the social role of the class as an eventful encounter and the valorization of the child as a proposing and creative subject, the work used the fabulation as a mechanism to test negotiation procedures and to stimulate ways of living and interacting. contact from dissent.
\end{abstract}

\section{KEYWORDS}

Creation process. Fabulation. Dissent. Cooperation. Political Imagination.

RESUMEN - Morando la disensión, germinando la alegría - Este artículo presenta el trabajo artístico "Convención Mundial de Países Imaginarios" realizado durante una residencia artística en la ciudad de Nova Lima, Minas Gerais, en la Escola Benvinda, que acogió a parte de los estudiantes desplazados por el delito ambiental ocurrido en la ciudad. de Brumadinho de la presa de mineral de la empresa minera Vale do Rio Doce. Trabajé en esta escuela con la clase de tercer año de 


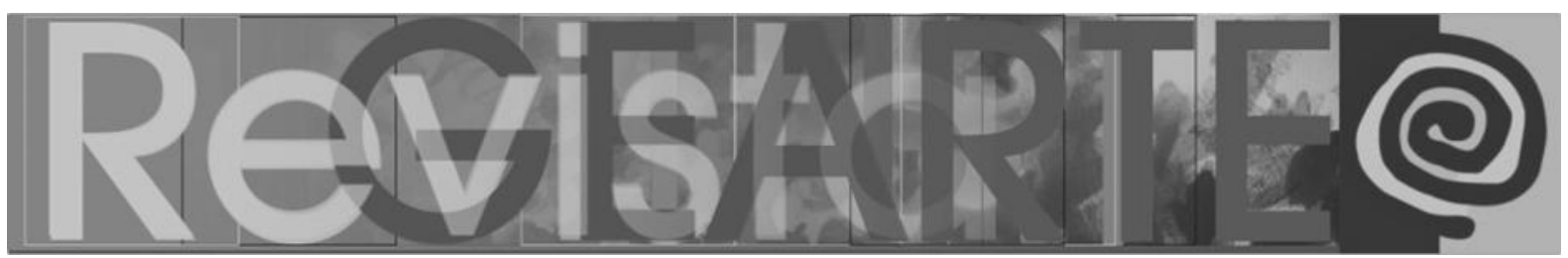

primaria, en la clase de la maestra Marcia Costa durante aproximadamente un mes. El proyecto se desarrolló a partir de una serie de encuentros, en los que se buscó la fábula de una convención mundial de países imaginarios, lema para debatir conflictos ya existentes y estimular la imaginación de otros futuros posibles. A partir de estas premisas, los estudiantes participantes se hicieron responsables de elaborar y representar sus respectivos países imaginarios, así como su cultura, escritura, idioma, bandera, vestuario, códigos, voces, valores, deseos, entre otros, ubicándose como protagonistas en un proceso de diseño de políticas alternativas para la construcción de un nuevo mundo. Así, con el fin de reforzar el rol social de la clase como encuentro eventual y la valorización del niño como sujeto proponedor y creativo, la obra utilizó la fabulación como mecanismo para probar procedimientos de negociación y estimular formas de vivir e interactuar. contacto de la disidencia.

PALABRAS CLAVE

Proceso de creación. Fabulación. Disentimiento. Cooperación. Imaginación política.

Importa quais histórias contar para contar histórias; importa quais nós atam nós, quais pensamentos pensam pensamentos, quais descrições descrevem descrições, quais vínculos vinculam vínculos. Importa quais histórias fazem mundos, quais mundos fazem histórias (Donna Haraway, 2016, p.18).

Era outubro de 2019 quando cheguei à sede do Jardim Canadá Centro de Arte e Tecnologia, ou Ja.Ca (Figura 1), como o conhecemos, um espaço de arte independente, em Minas Gerais, que, depois de um período focado nos trabalhos de organização e produção de conteúdo para outras organizações culturais como modo de gerar subsistência, volta-se para a sua estrutura autofinanciando uma residência artística para a qual fui selecionado juntamente com mais dois artistas. Ao chegar no espaço, vi um terreno que possuía bastante área aberta e, no meio, um galpão onde funcionava uma oficina, a marcenaria e um complexo de aproximadamente seis containers arranjados de modo a configurar uma sala de guarda, uma biblioteca, um escritório, uma cozinha, espaço de convivência e três dormitórios. Ao me aproximar, logo percebi que estava perto de minas de ferro, material abundante naquele território, que fomenta uma prática que dá nome àqueles que nascem no estado. 


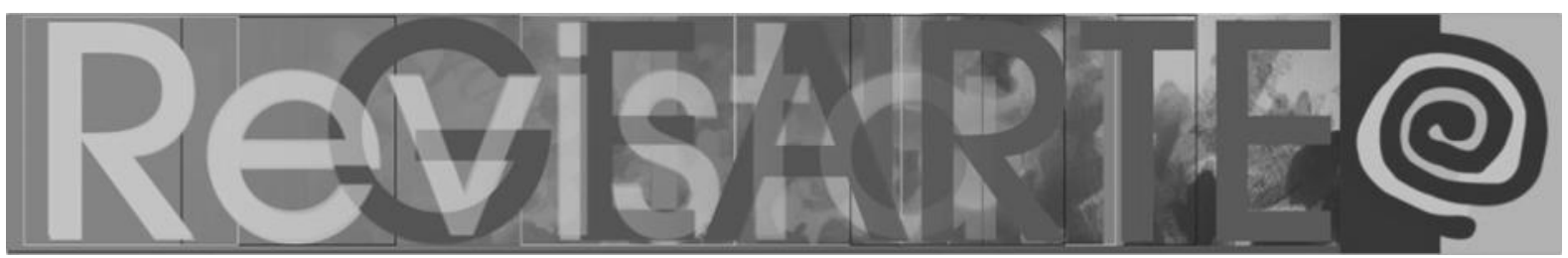

Figura 1 - Sede do Jardim Canadá Centro de Arte e Tecnologia Ja.Ca.

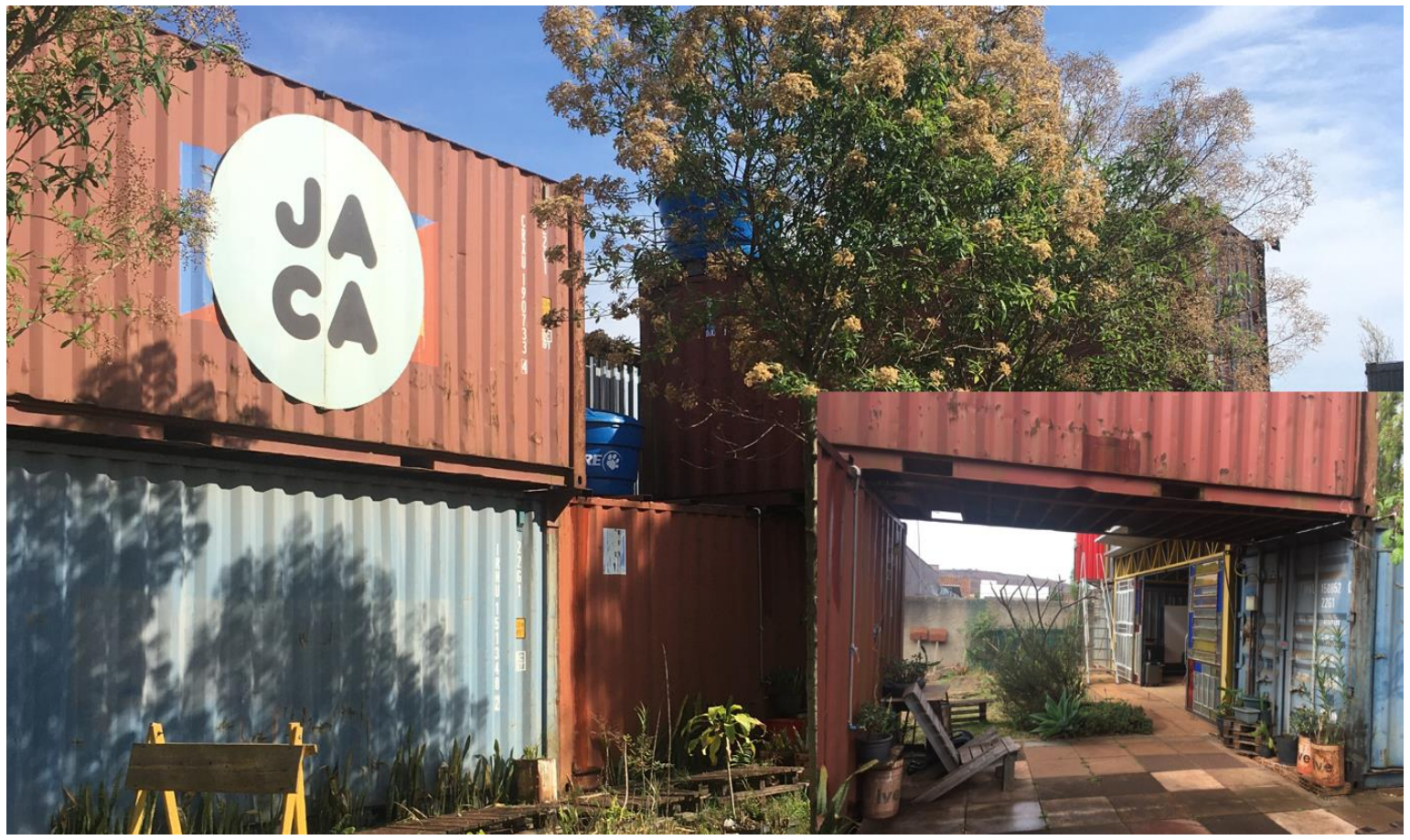

Fonte: Acervo de Gustavo Torrezan (2019).

A receptividade mineira fez jus à fama de que seus habitantes são acolhedores. Depois de escolhermos em qual quarto cada um iria se alojar, todos nós sentamos em roda e nos serviram café e pão de queijo "de verdade", como comentaram. Estávamos, tanto os artistas participantes quanto os organizadores, envoltos na alegria de iniciar uma nova experiência em um contexto novo ao mesmo tempo em que estávamos ansiosos por pensar o que poderia ser produzido durante aquele mês de residência. Enquanto o corpo se ambientava com aquele lugar e as conversas iam buscando pontos em comum em meio a olhos nos olhos e sorrisos abertos - cartões de visita desses tipos de encontro aconteciam —, começou a surgir, como assunto, o contexto em que aquele espaço independente estava inserido, o que eu já havia percebido na chegada. Estávamos há poucos metros, aproximadamente duas ou três quadras, da mina de ferro ativa, a Capão Xavier (Figura 2). Mais tarde, fomos espiar essa mina algumas vezes, sendo sempre expulsos pela segurança. Da conversa sobre território, inevitavelmente veio o assunto da cidade que fica a pouquíssimos quilômetros dali: Brumadinho. 


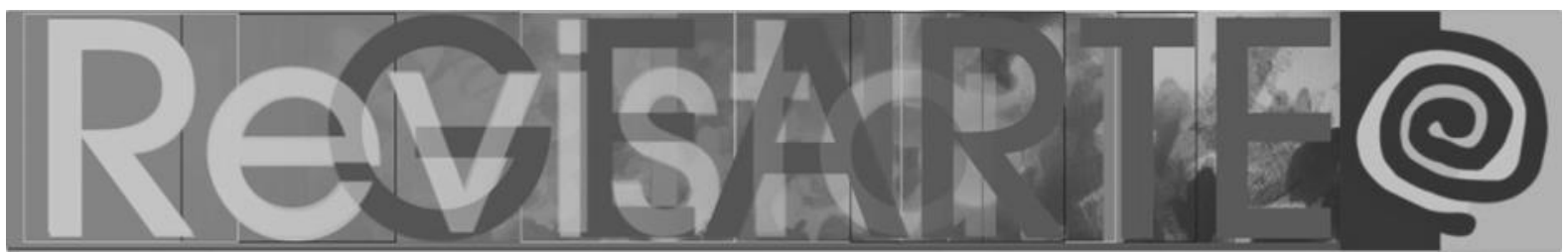

A cidade, que ficou conhecida por conta do Museu Inhotim, passou também a ser reconhecida como o lugar de um dos maiores crimes ambientais da história recente do país, que foi provocado pela mineradora Vale do Rio Doce, com o rompimento de uma barragem de rejeitos de minério que soterrou parte da cidade exterminando vidas e o ecossistema local. Não podíamos esconder o interesse pelo assunto, que fora amplamente noticiado, mas desejávamos ouvir aqueles que viram de perto, e sem as lentes da mídia, o que aconteceu. A conversa sobre essa ferida, que até hoje está aberta, estendeu-se por horas.

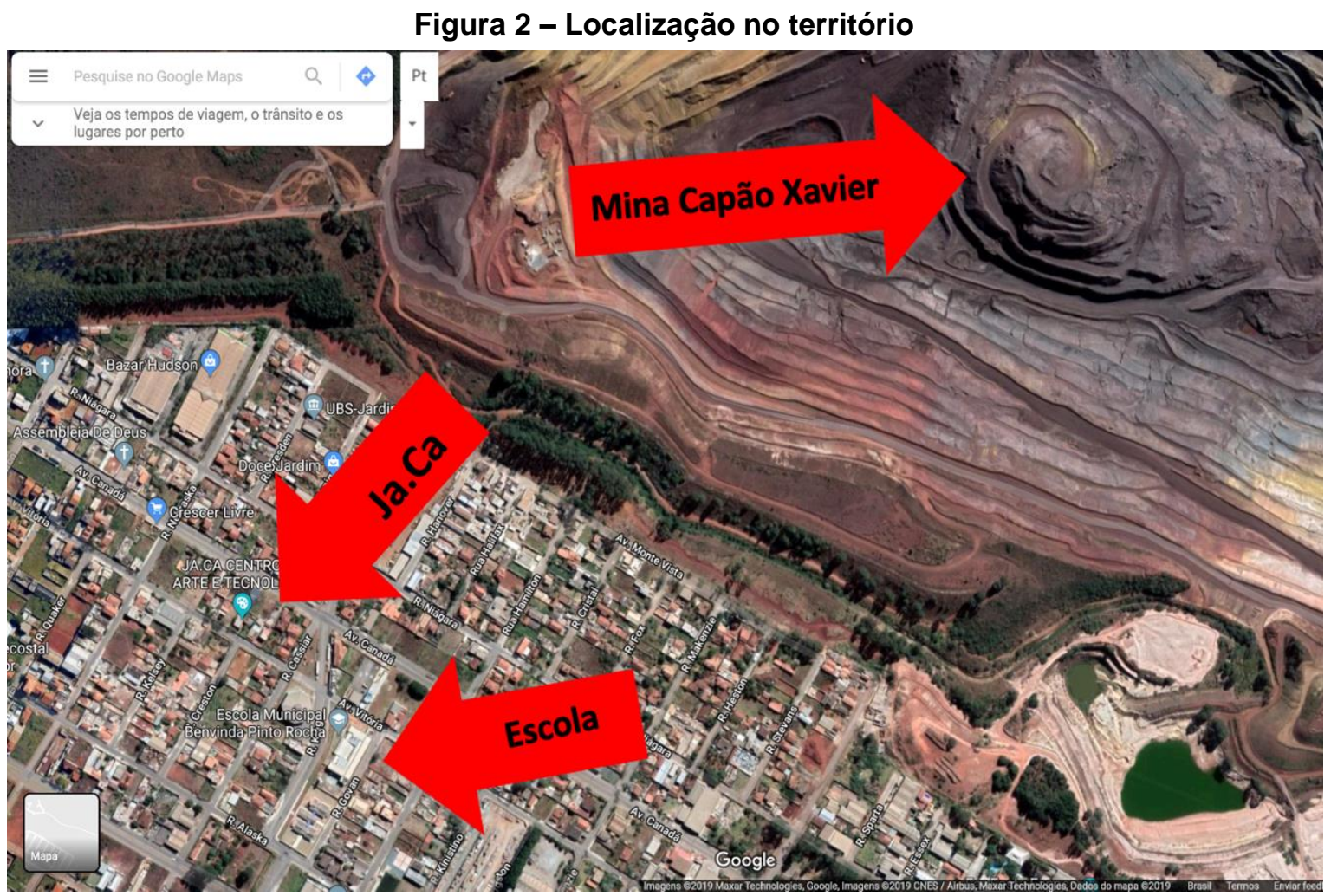

Fonte: Acervo de Gustavo Torrezan (2019).

No prolongamento da conversa, soube que parte dos estudantes de Brumadinho vieram estudar na Escola Benvinda, que fica a uma quadra do espaço onde estávamos. Aquela foi uma informação que me marcou e disparou a determinação de caminhar pelo bairro para conhecer a redondeza logo no início do outro dia, já buscando possíveis interpelações que pudessem provocar uma investigação que culminaria em um novo trabalho artístico. 


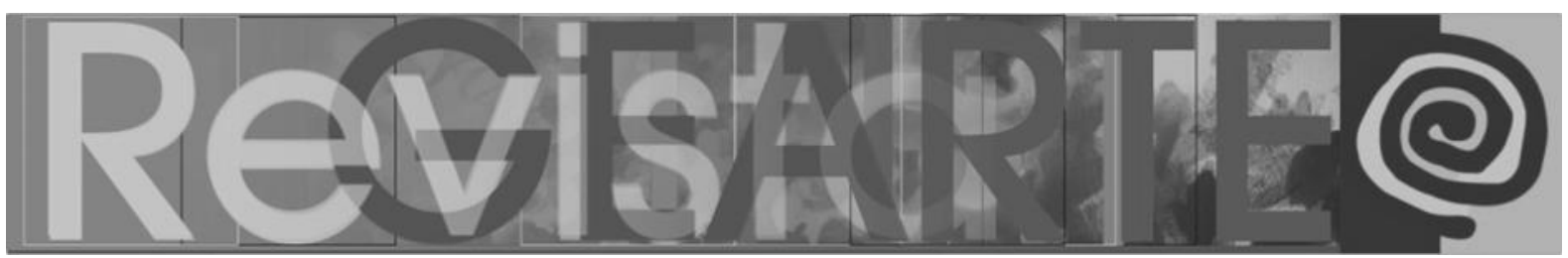

Na manhã seguinte, durante a caminhada pelo bairro, parei em frente à escola (Figura 3) e fiquei observando-a, do outro lado da rua, por horas - seu movimento, sons, o que conseguia perceber de organizações, o festejo do intervalo, a saída do turno da manhã. Ali, da calçada, observando uma profusão de questões, veio em meus pensamentos, junto com todas as questões, o inevitável desejo de trabalhar com aquela escola, sem muito saber o porquê e como para além da intenção de pensar e experimentar aquilo que produz vida, e não morte... tentando traçar um contraponto ao outro chamamento que havia me atido na caminhada: a mina de extração de minério de ferro.

\section{Figura 3 - Escola Benvinda}

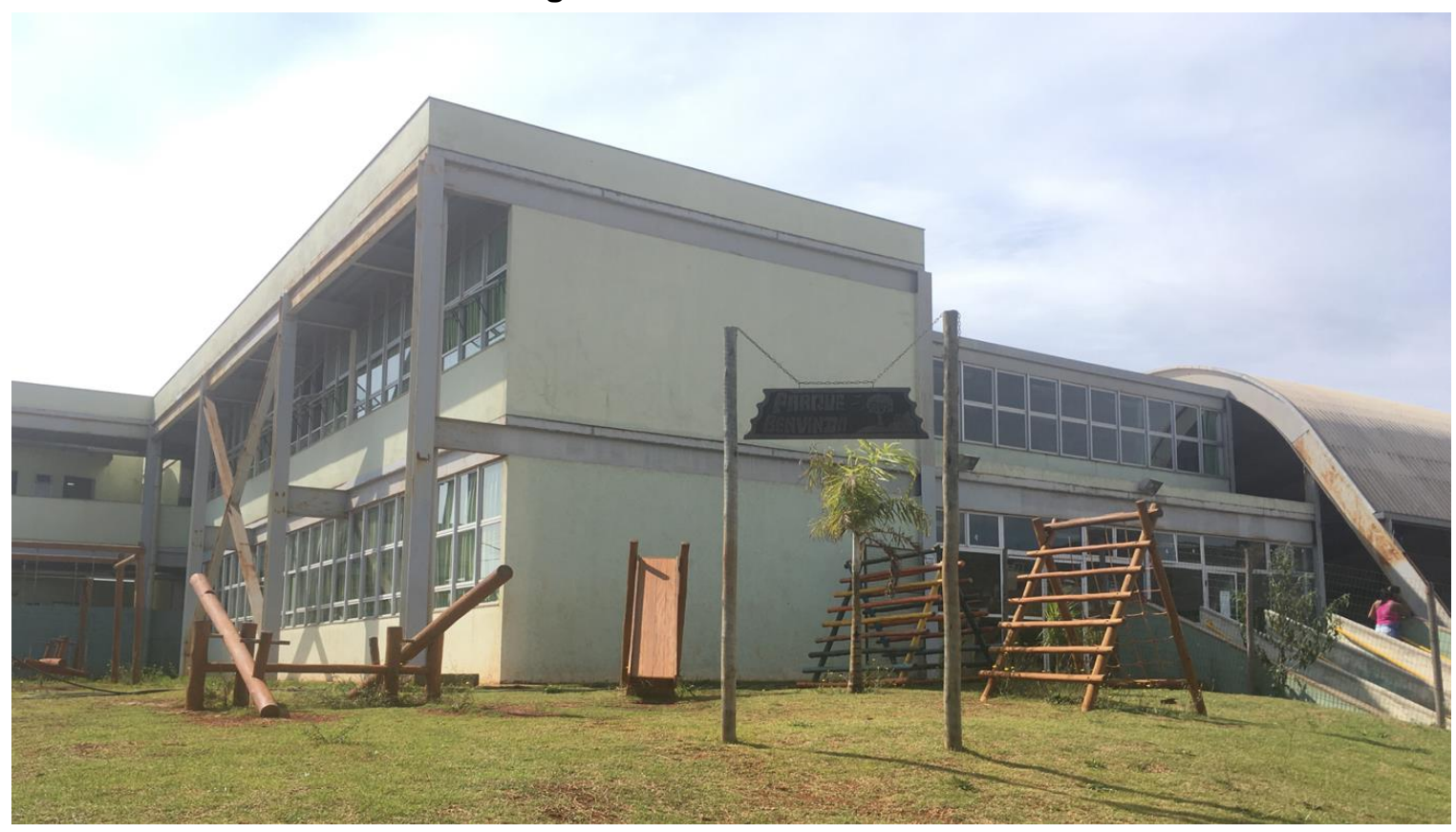

Fonte: Acervo de Gustavo Torrezan (2019).

Era um desejo de pensar a produção de vida tal qual nos convida a pensar a permacultura quando diz que a energia não se dissipa, mas se transmuta de diferentes modos e formas, podendo ser estimulada in loco. No caso, na escola. Tinha a percepção, naquele momento, de que havia um acumulado de energia naquela escola em torno de questões como, a começar por uma já tradicional, "O que é produzir, fazer, uma Escola?", passando por outras como "O que se pratica nesse lugar?" "Que tipos de utopias ou de distopias se experimentam ali?", "Qual 


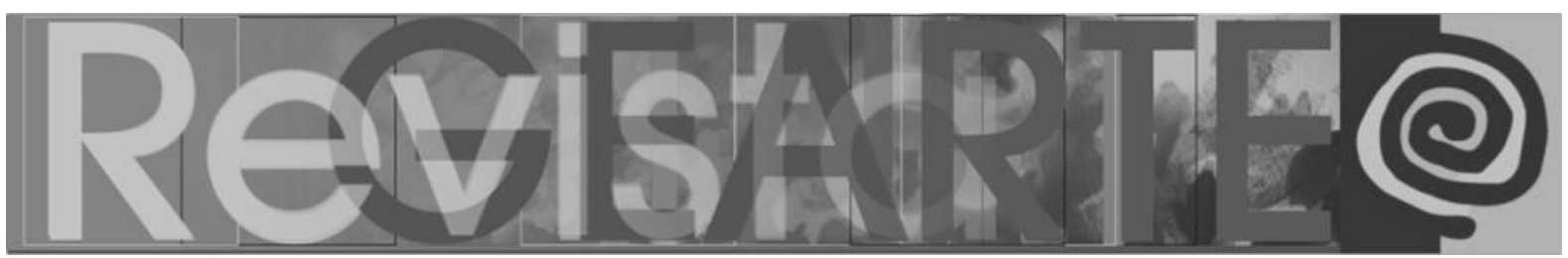

o tipo de imaginação política é fomentada ali?" e "Como lidam com o contexto e acontecimentos em que a Escola está ou foi inserida?". Ainda havia uma curiosidade que perpassava minha pouca experiência com a educação formal básica: "Como é uma aula nessa escola?", e, por fim, "Será que ela carrega os traços das aulas que frequentei como estudante ou a prática de ensino se transformou recentemente?".

Diante de tamanhos questionamentos e da determinação de trabalhar naquele lugar durante o período da residência, o desafio inicial foi como começar. O que propor para chegar?

Voltando ao Ja.Ca, passei a tarde pensando, e a ideia que ficou fixada como potente foi a de criar junto, na escola, com os estudantes de lá, uma convenção dos países imaginários, em que os representantes desses países imaginassem juntos o futuro do planeta, já que este, considerando o que fazemos e produzimos, não tem outro destino senão a catástrofe. Decidi, naquela tarde, que iria trabalhar a partir dessa proposição com o ensejo de instigar o que chamo de imaginação política ou da possibilidade de intervalar - um intervalar entre a utopia e a distopia que faz multiplicar a energia, tal qual propõe a permacultura.

Intervalar como a produção de um verbo, de ação de intervalo - momento mais esperado pelos estudantes - das possibilidades de distensões, de atravessamentos que movimentem, interrompem, mudam, hiatam os fluxos que estão impostos a nós todos, mas especialmente àquelas crianças que vivenciam na pele, no corpo, uma certa tristeza, por exemplo, dos crimes ambientais, das escolas tradicionais, das aulas apáticas, dos ordenamentos que encurtam horizontes, de um suposto futuro predeterminado etc.

Com a proposição do trabalho, fomentava um processo que fizesse como um experimento com o qual fosse possível, metaforicamente, arar a terra, afofá-la, adubá-la, afetando-a, ou retornando a ela, e nela, o sentido de imaginação política. Dessa forma, retomava também a imaginação política da escola, do ensino, da 


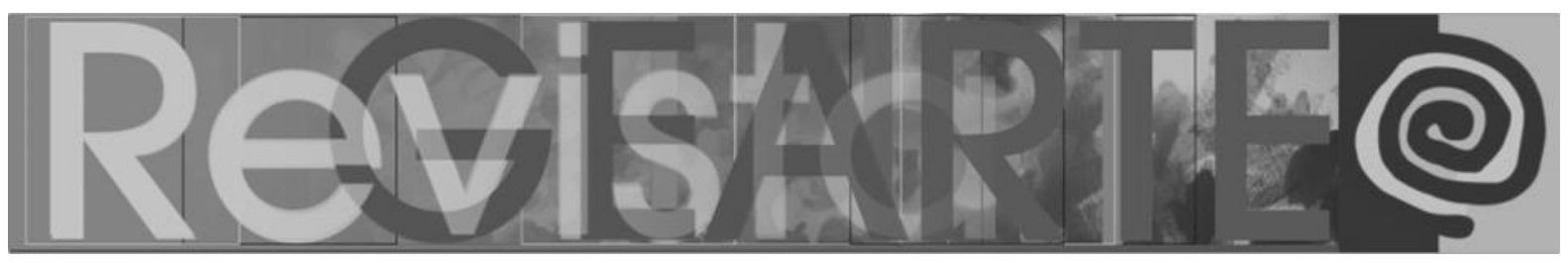

educação - campos de atuação que são pautador por vezes pelo sentido de massificação, de padronização e de "média" que neutralizam as diversidades motivado por uma aposta tal qual a de Antonio Carlos Amorim (2020, p. 156) de que "[...] toda vida singular merece ser sonhada".

Do pensamento inicial sobre o que poderia ser a pesquisa que culminaria no trabalho, bati à porta da escola, onde conversei com a diretora sobre a possibilidade de frequentar e trabalhar ali durante o mês da residência. Ela de pronto aceitou, porém condicionou que deveria trabalhar com todas as crianças juntas, ao mesmo tempo, nos intervalos.

Pensei no que havia visto de fora da escola: um pátio cheio de crianças, e elas querendo brincar desesperadamente. Nesse momento, lembrei-me de Etienne Samain (2011, p. 31) quando indica que "[...] o artista é alguém que corre riscos. E somos todos, no entanto, artistas natos. Será, então, que precisamos de tantas outras seguranças, de tantas outras "razões" para tomar a sério nossa imaginação?"

Aceitei a condição e me coloquei diante do desafio. Mas como se pode pressupor, a primeira atividade não deu certo (figuras 4 a 6). Entre o uso de uma caixa com dezenas de caixas de bastão de cera e uma resma de papel sulfite A4, produzi um pequeno caos no intervalo. Nesse início, o tumulto de tentar dialogar para que aproximadamente 150 crianças desenhassem não foi a principal questão de incômodo, mas, sim, os inspetores de pátio, que gritavam e apontavam o dedo tolhendo e ordenando toda e qualquer possibilidade de alegria e de uma experimentação mais livre. 


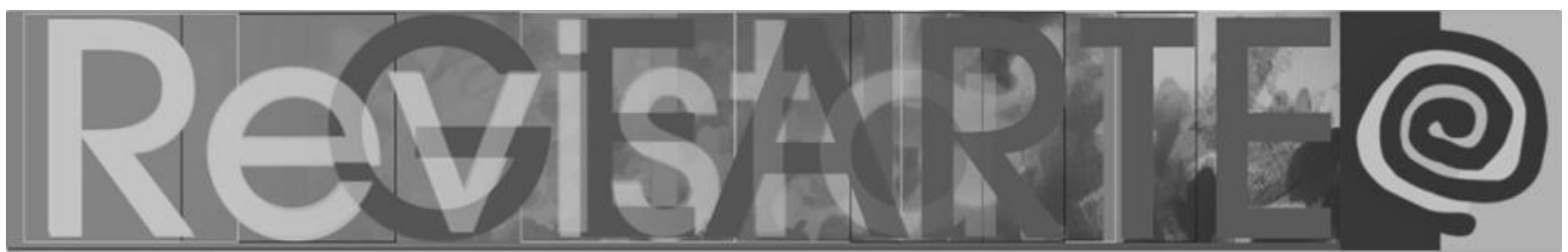

Figuras 4 a 6 - Primeira atividade na escola e registro do "inspetor" organizando os estudantes no pátio
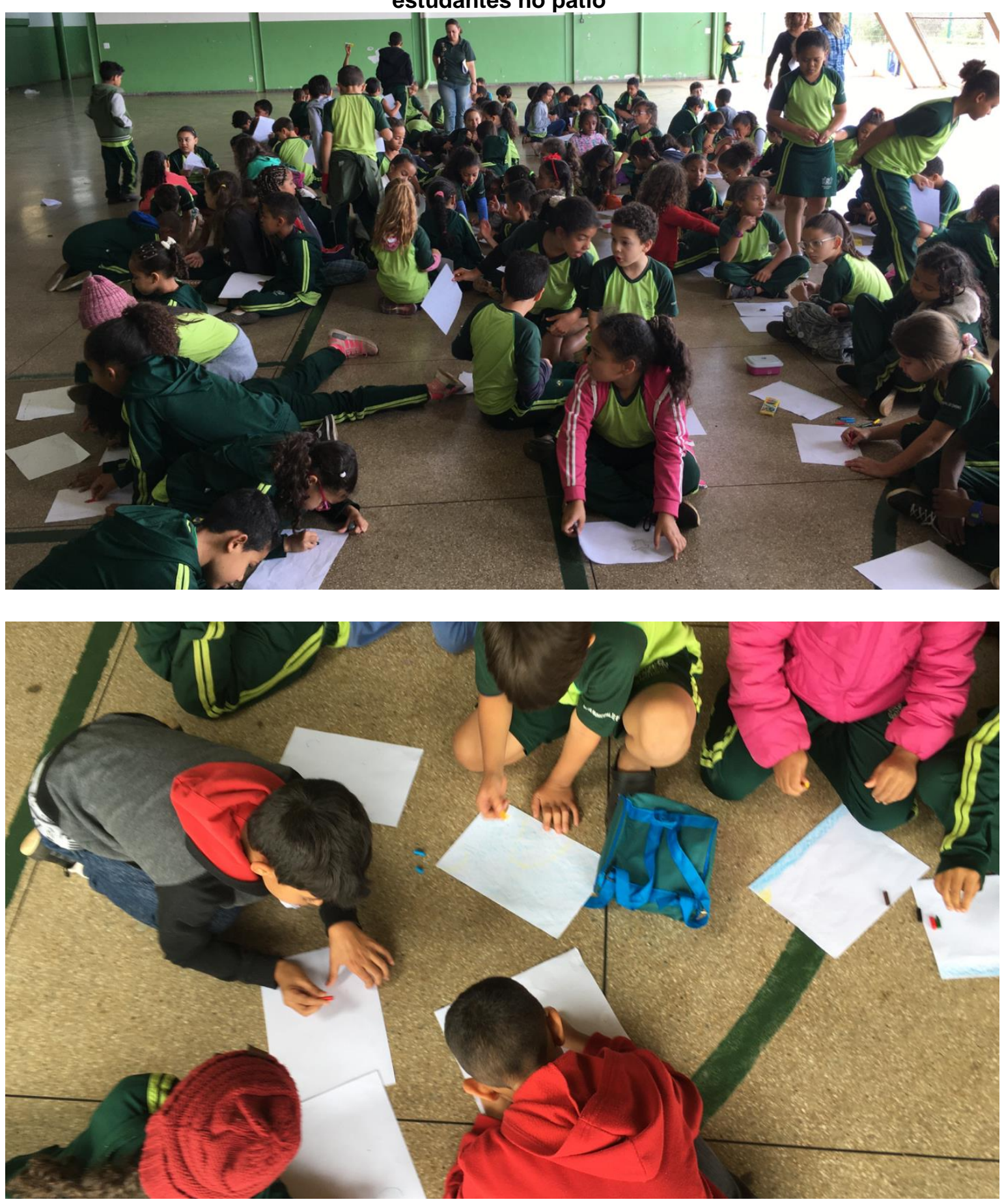

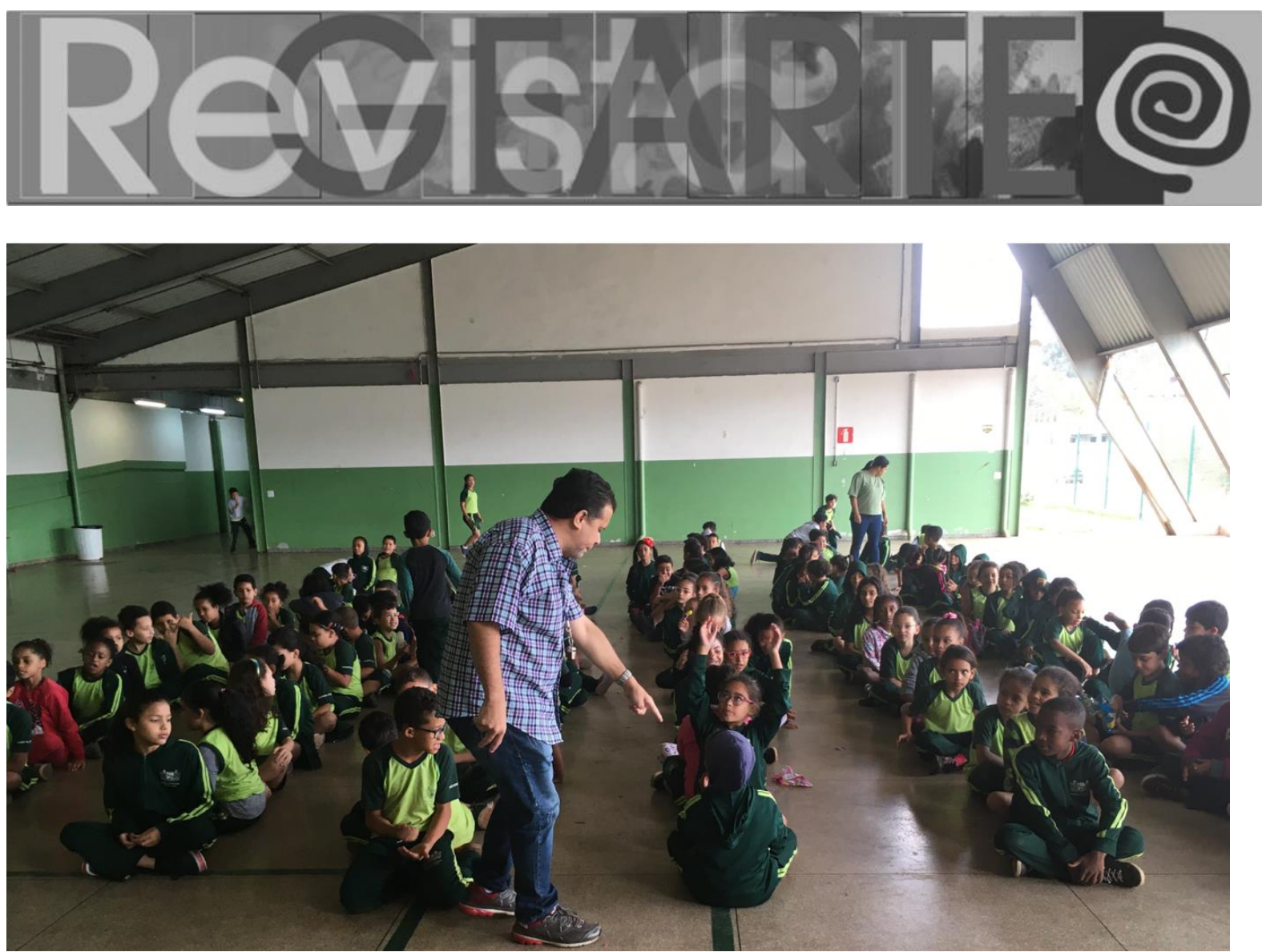

Fonte: Acervo de Gustavo Torrezan (2019).

Corri o risco e quase desisti. Percebi que aquele arranjo não daria certo, e notei que criança trabalha na lógica do jogo, que é capaz de reter sua atenção, geralmente curta, por mais tempo. Então, depois de testar essa ação inicial, fui conversar novamente com a diretora, dizendo que não seria possível continuar daquele modo com toda a escola. Ela, por sua vez, convidou-me para ir à sala dos professores e contar a eles, em detalhes, sobre a minha intenção, considerando também que já haviam percebido "um corpo estranho" produzindo muito alvoroço com os estudantes.

Ao contar a ideia inicial, e mesmo informando que não a tinha completamente definida, ouvi uma enfática resposta da professora Márcia Costa, responsável pela turma do terceiro ano: "Eu quero que você trabalhe na minha sala! Você é muito bem-vindo lá!", comentou sorrindo.

Considero que inventar um trabalho de artes é um modo de habitar um problema, de tomar para si uma questão não resolvida sobre a qual parece que nada mais pode ser feito a não ser resolver tal questão. É uma espécie de urgência ordinária, um xadrez, um enigma que precisa ser solucionado. Naquela residência, 


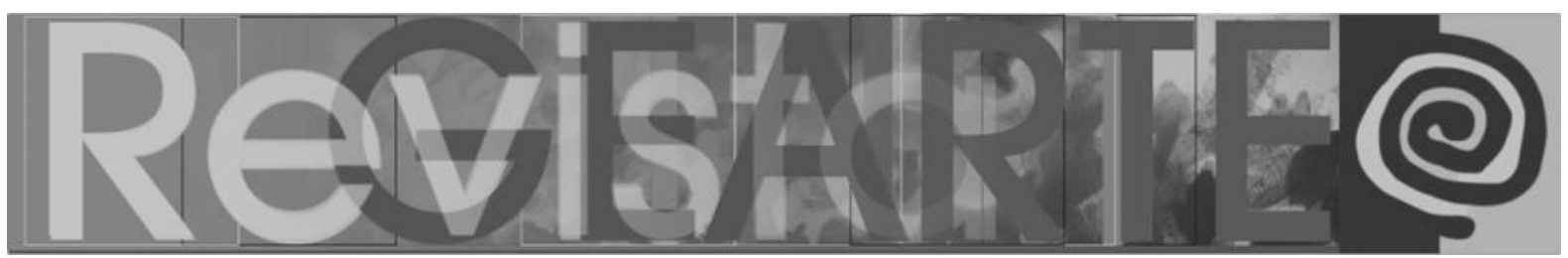

tinha disparado o problema, e precisava continuar me ajustando e adaptando o que estava a criar, tal como convida a pensar Deleuze (2013, p. 89) - "Os processos são os devires, e estes não se julgam pelo resultado que os findaria, mas pela qualidade dos seus cursos e pela potência de sua continuação" -, me abrindo para criar junto com os estudantes da escola. Produzir um trabalho de arte é, de certo modo, engendrar uma máquina abstrata que não possui forma ou padrão de funcionamento e que, ao ser ligada em "resolver problemas", aponta possibilidades e mudanças. Assim, partindo do desejo de trabalhar naquele contexto, entrei no pátio, e dele, na sala de aula para fazer junto com os estudantes.

Quando começo a criar um trabalho, algo me chama, e desse chamado vou juntando questões, pontos, inquietações, fabulações e me entregando aos acontecimentos que surgem de maneira a criar conexões que traçam um campo, um território que me faz habitar o problema que é construir o trabalho.

Habitar o problema de produzir arte com crianças que passaram por tamanho impacto que é experienciar um crime ambiental de tamanha magnitude dentro de uma sala em uma escola e em encontros que se figuram como aulas é, lembrando Donna Haraway (2016), uma maneira de estabelecer continuidades de modos de estar e de fazer mundos, pois, se não resolver o problema da criação, tudo se faz uma catástrofe tal qual o próprio mundo em que vivemos. A autora comenta que não está "[...] interessada em reconciliação ou restauração, mas profundamente comprometida com as possibilidades mais modestas de recuperação parcial e de nos darmos bem juntos. Chamemos isso de conviver com o problema" (HARAWAY, 2016, p. 10). Tomo para mim o pensamento, e, a partir dele, abro novas possibilidades de operação e realização para o trabalho.

"Conviver com o problema", como entendo a expressão, também é um modo de laboratorializar, de experimentar, de produzir arranjos e pensamentos em devir. E, por vezes, hesitar e desacelerar as soluções que se pretendem mágicas como, por exemplo, levar um pensamento e um planejamento pronto que pudesse ser 


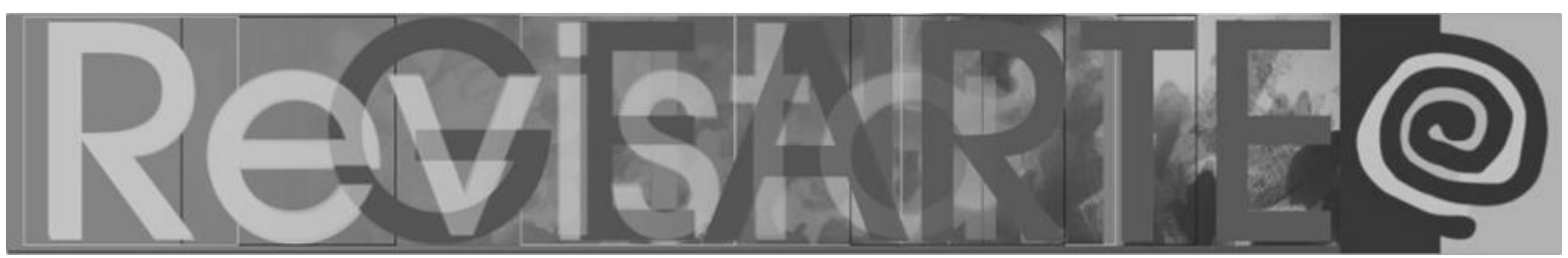

executado na escola sem a consideração daqueles que lá estavam. É importante, nesse caso, deixar-se contaminar por aquelas situações de maneira a perceber e se afetar pelas forças que lá estão, compondo com elas arranjos que venham a potencializar o trabalho. "Habitar o problema" é também vivenciar as situações nos seus entrecruzamentos, que acionam diferentes perspectivas que operam motivações, engajamentos e ações. Assim, aceitei entrar na sala da turma do terceiro ano para misturar meus trabalhos às aulas da professora Márcia Costa.

\section{Habitando o problema}

Com essa turma, consegui um grupo menor para trabalhar e a possibilidade de aprofundar a proposição de fazer junto com alguns estudantes do terceiro ano, porém tinha o problema de construir o trabalho junto, sem saber muito bem o que seria, como seria realizado ou a qual resultado chegaria e ter que esperar. Apesar dessas dúvidas, apostei na lógica do encontro por acreditar que ele é, por essência, uma aula.

Entendo que o encontro deve afetar, ou seja, produzir uma marca que nos movimente, fazendo experimentar o que talvez nunca houvesse sido experimentado, ou mesmo experimentar uma mesma coisa de outro modo. Assim, produz processos de diferenciação, já que, acredito, educação é a prática da diferença. É um processo em que nos diferenciamos dos lugares, modos, percepções, reflexões, incômodos e tranquilidades em que estávamos. Em outras palavras, encontro é movimento. Ainda que, por vezes, o ensino formal, por meio de diferentes estruturas, teime em massificar, igualando tudo e todos em um todo mediano que não tem forma, opinião, memórias, desejos, singularidades, estávamos todos ali dispostos a experimentar esse encontro.

Segui as recomendações da professora Márcia e voltei logo pela manhã para receber os estudantes no pátio e, junto com ela, conduzi-los à sala de aula. Esse foi o rito que fizemos durante os dias em que trabalhamos juntos. Naquela 


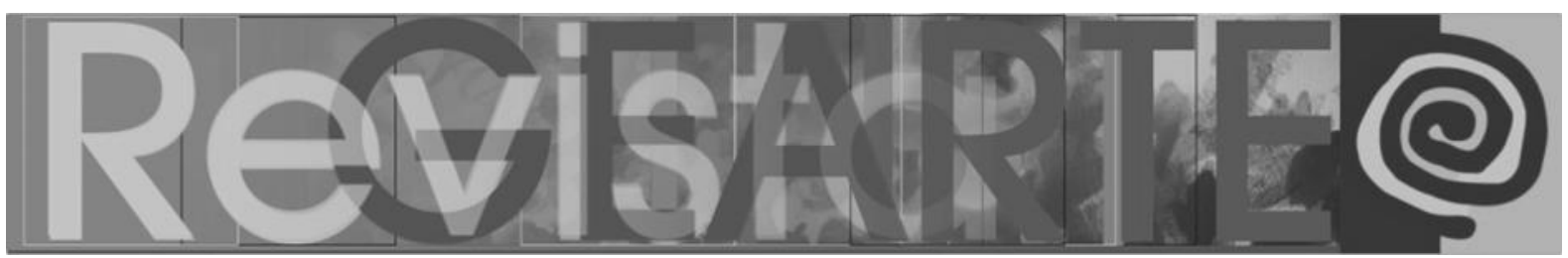

manhã, tinha em mãos uma resma de papel e alguns tocos de bastão de cera que haviam sobrado do encontro do dia anterior.

Ao chegar na sala, eu me deparei com um espaço novo, limpo e bem cuidado, mas semelhante àqueles que frequentei na infância: repleto de carteiras ordenadas, lousa com vestígios do dia anterior e cartolinas de cor pistache, rosa e azul celeste nas paredes. Ainda me deparei com a chamada para aferir a presença. Os estudantes estavam felizes por perceberem que a rotina das aulas aparentemente iria mudar, mas estavam, assim como eu, ansiosos e apreensivos pelo que poderia acontecer.

Como era o primeiro encontro, havia preparado algo no dia anterior para apresentar, porém, como em todo trabalho artístico, sabe-se que o projeto é totalmente diferente da obra final. Estava com o projeto preparado e fixo em minha cabeça, quando olhei nos olhos da turma toda que estava em minha frente me olhando com determinação e abertura, com sorriso no rosto. Naquele momento, algo em mim me fez, como um flash, rememorar o que havia percebido logo no início das caminhadas em minha residência artística - crianças brincando no intervalo foi umas das coisas que me chamou a atenção quando parei do outro lado da rua para olhar a escola através do seu alambrado.

A brincadeira ${ }^{1}$ apareceu como uma luz que indicava por onde seguir naqueles milésimos de segundos de hesitação que tive. A dinâmica com crianças é a do jogo, da brincadeira. A atenção delas não se retém por muito tempo, pelo menos como pensamos a atenção na vida adulta. Então, comecei a contar, a narrar para elas uma história que era a minha história de como cheguei até ali e o que tinha como convite para fazermos juntos, fazer com elas, a partir de dinâmicas rápidas no início do dia, antes das aulas da professora, para poder estar junto sem muito atrapalhar os conteúdos curriculares e não ocupando o tempo todo do dia da turma. Começamos a nos divertir e a sorrir juntos e a brincar soltando, pouco a pouco, o condicionamento corpóreo tão comum nas salas de aulas. 


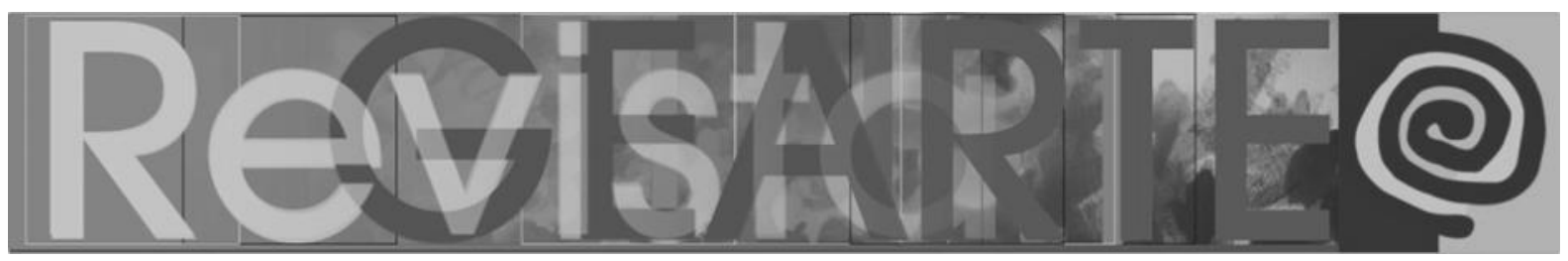

Com os corpos começando a se soltar e com sorrisos disparados, propus, então, que brincássemos a partir de perguntas disparadoras, que eu iria trazer (uma por dia) ou que poderíamos pensar juntos a partir do que quiséssemos, tendo como referência o convite de Antonio Lafuente (2020) para começar toda ação de fazer juntos pelo perguntar. E assim fizemos.

Das inúmeras formas como poderia apresentar o processo do trabalho, escolho uma que mostra parte das perguntas que dispararam cada proposição e encontro nos dias, tecendo relações com outros pensamentos. Cabe dizer que, no processo, ao final, cada parte pensada produziu o engendrar conectivo para compor na soma em favor de um todo que, organizado circunstancialmente, configurou-se como a Convenção Mundial dos Países Imaginários.

A partir de cada uma dessas partes, encontros, foi sendo combinado um pouco de cada país imaginário, tendo a criação de dinâmicas que construímos juntos, disparadas a partir de perguntas.

Apresento, a seguir, uma seleção das perguntas realizadas, privilegiando as correlações dessas com outros pensamentos que prolongam as linhas de força que se mostraram como aberturas de caminhos e possibilidades. Opto por não me ater às reações ou registros e memórias dos estudantes para deixar espaço para a imaginação dos leitores e não correr o risco de reducionismos. Do mesmo modo, é uma opção apresentar apenas etapas do processo em uma espécie de escrita com diferentes linhas que possui como ponto de conexão a Convenção Mundial dos Países Imaginários.

A primeira pergunta, pensada logo depois de exercícios/brincadeiras que fizeram soltar o corpo, foi um tanto abstrata e confusa para crianças de 8 e 9 anos, mas possibilitou uma rica discussão entre nós. Partimos da imaginação, dos personagens de histórias às possibilidades de ser no mundo. Também de como a fala, a palavra, que pode ser dita de muitas formas, acaba por fundar, inaugurar, mundos. Comentamos, ainda, que cada um já conhecia ou tinha consigo uma 


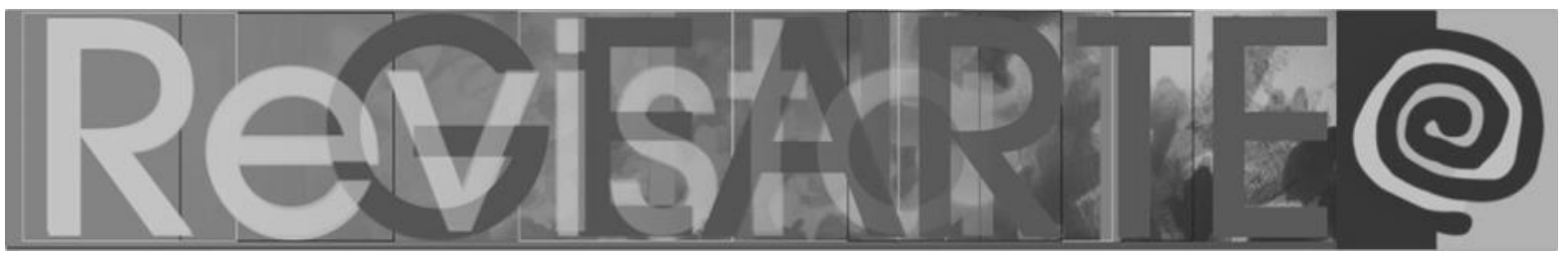

potente máquina, que é a imaginação criadora, e que ela nos leva a lugares incríveis se a utilizarmos como ferramenta.

Quais outras identidades podemos ter? foi a pergunta que disparou o pensamento sobre o idioma do país imaginário. Como poderíamos inventar uma língua que escapasse da boca, que produzisse o prolongamento do desenho na palavra e da palavra como desenho? Com essas perguntas, foram distribuídas folhas em branco e bastão de cera para que os estudantes pudessem escrever (desenhar) o idioma do país imaginário - uma proposta inicial para alargar as possibilidades imaginativas e sair, de início, da rota determinística de um modo certo de falar, escrever e expressar que é comum nos anos escolares iniciais (figuras 7 e 8).

Figura 7 - Registro do processo de escrita da carta convite para visitar o país imaginário

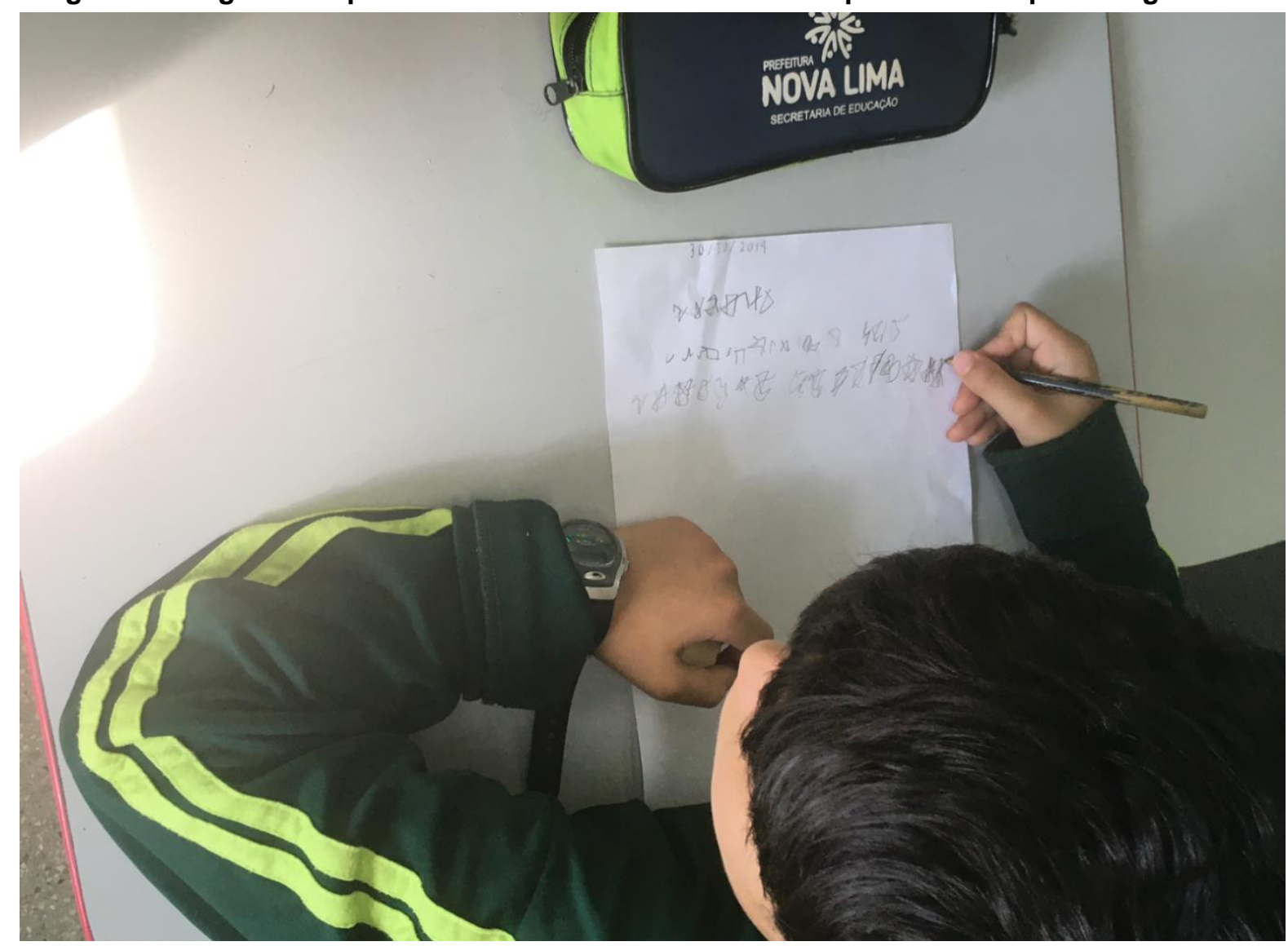

Fonte: Acervo de Gustavo Torrezan (2019). 


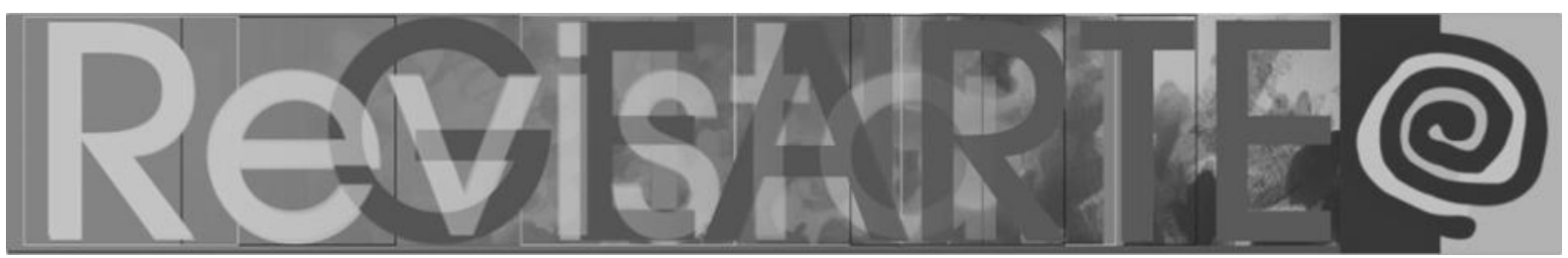

É interessante notar que muitos tinham, ainda como referência, a alfabetização do idioma utilizado, criando apenas pequenas variações, e o letramento, que estava em curso, pouco se atendo às outras possibilidades de escrever e de criar sua própria língua. O fato é que esse idioma que falamos, ou mesmo os pressupostos acelerativos de conteúdos e de habilidades que comumente temos nos currículos escolares, costumam nos fazer esquecer.

Figura 8 - Carta escrita na língua do país imaginário com convite para visitar seu país. Autora Nayara da Silva Freitas de Melo

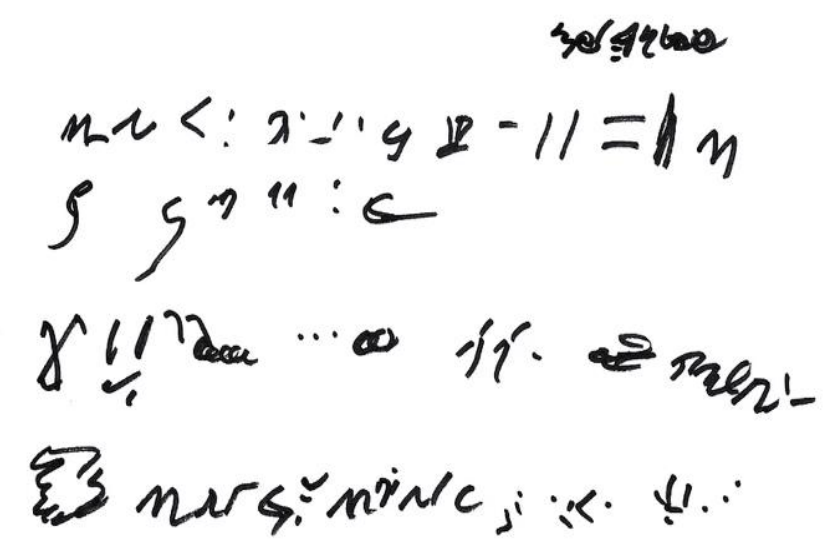

Fonte: Acervo de Gustavo Torrezan (2019).

Nessa atividade inicial, acabei sendo mais presente e atuando como mediador que estimulou descondicionamentos, instigando a fazer diferente e a ir para onde não se tinha ido ou também, muitas vezes, retomando a possibilidade de desenhos que não fossem só figuras e de escritas que não fossem só palavras.

É a possibilidade de pensar as identidades que se têm e ainda aquelas que se pode ter e desejar, saindo dos pressupostos ou definições que nos prendem e condicionam a "formalismos" que nos deixam pouco experimentar outras possibilidades.

Fazer proliferar a imaginação política que produz novos e outros mundos para além desse que está sucumbindo é apostar num recomeço. Esse foi o gérmen, a semente, a centelha, a faísca do big bang do país imaginário. Um 


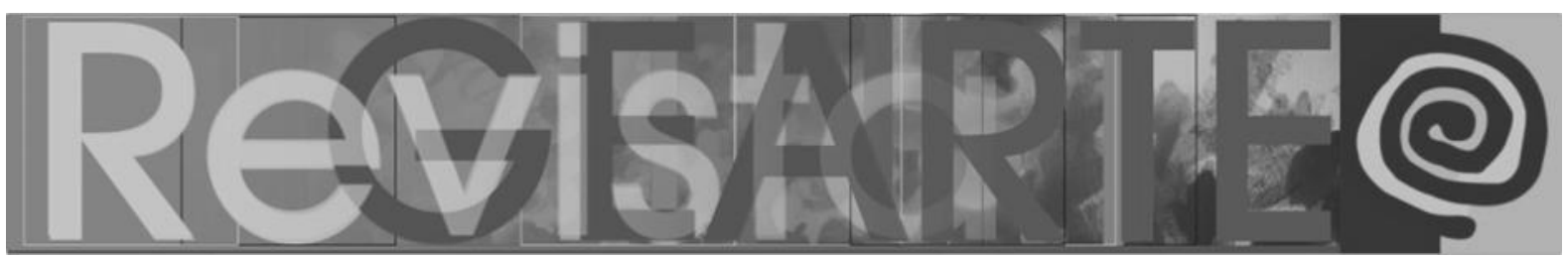

começo, um recomeço para aquelas crianças, pois, como nos lembra os escritores anônimos autodenominados TIQQUN (s/d, p. 13),

[...] recomeçar nunca é recomeçar alguma coisa. Nem retomar um assunto ali onde a gente o tinha deixado [ou escondido por conta de um trauma, um acontecimento fatal, um crime ambiental... $]^{2}$. O que a gente recomeça é sempre outra coisa. É sempre inaudito. Porque não é o passado que nos impele a isso, mas precisamente o que nele não adveio. E porque somos também nós mesmos, então, que recomeçamos. Recomeçar quer dizer: sair da suspensão. Restabelecer o contato entre nossos devires. Partir, de novo, dali onde estamos, agora.

Após friccionar as identidades, foi produzida uma escrita que é desenho e um desenho que é escrita, tendo como propulsora a brincadeira de desaprender, que é o mesmo que descondicionar os pressupostos.

Ao final do encontro, que levou quase toda a manhã, vieram indícios dos próprios estudantes do que poderia ser a pergunta geradora. Voltei para o Centro Cultural com a percepção de que algo bom havia se iniciado.

Fomos para o segundo dia de atividade, seguindo os combinados para o encontro e com a percepção de que havíamos começado um vínculo ali e de que todos, tanto os estudantes quanto a professora e eu, estávamos felizes com o que acontecia.

Logo no encontro no pátio, os estudantes sorriram e pularam de alegria festejando minha volta, que, afirmei, aconteceria por vários dias.

Nos encontros seguintes daquela semana, as iniciativas foram da criação do nome dos países imaginários e da veste que eles, enquanto representantes dos países, iriam utilizar (figuras 9 a 13). Também foi inventado como se expressaria cada representante, por exemplo, como caminhava, dançava, se alimentava pequenas provocações que expandiam o modo como eles se colocavam nas carteiras, utilizavam o corpo ou mesmo realizavam ações como lanchar na escola. 


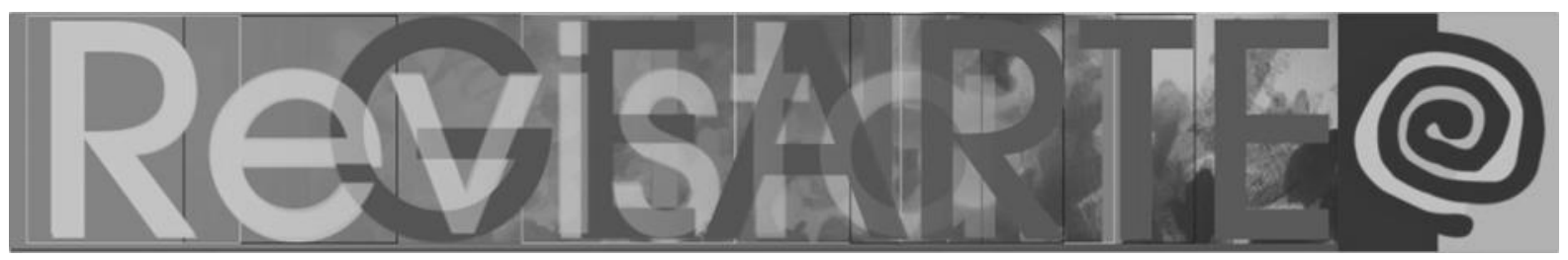

Figura 9 - Nome do país imaginário adaptado ao alfabeto latino.

Autora Nayara da Silva Freitas de Melo

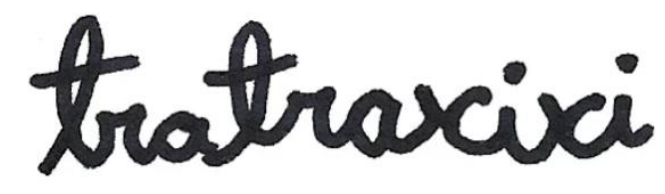

Fonte: Acervo de Gustavo Torrezan (2019).

As perguntas geradoras dos encontros seguintes foram $O$ que toca na $e$ com a pele? E ainda que marcas e que símbolos carregar? Como os inventamos? E aquilo que vestimos e o que representa? Quais discursos nosso corpo produz, recebe, disputa? Partimos dessas perguntas para, então, inventarmos o traje do representante dos países imaginários.

Do desenho inicial, foram feitos outros para adaptar as intenções às possibilidades construtivas rápidas e cabíveis dentro da dinâmica. Assim, criamos uma espécie de capa-parangolé que, vestida por cima do uniforme escolar, transpunha os estudantes para um outro lugar, que era justamente o inverso do que pretende toda uniformidade, ou seja, para uma experiência sensória de um corpo que dança na e com as camadas que o compõem, criando um outro que, investido dessa experiência, transmuta energia criando linhas de força de alegria e de liberdade. Mas, lembrando o poeta Waly Salomão (1996, p. 27),

[...] a relação do artista-propositor com o participante que veste o PARANGOLÉ [e aqui pra nós podemos pensar no traje do representante do país imaginário $]^{3}$ não é a relação frontal do espectador e do espetáculo, mas como que uma cumplicidade, uma relação oblíqua e clandestina de peixes no mesmo cardume. 


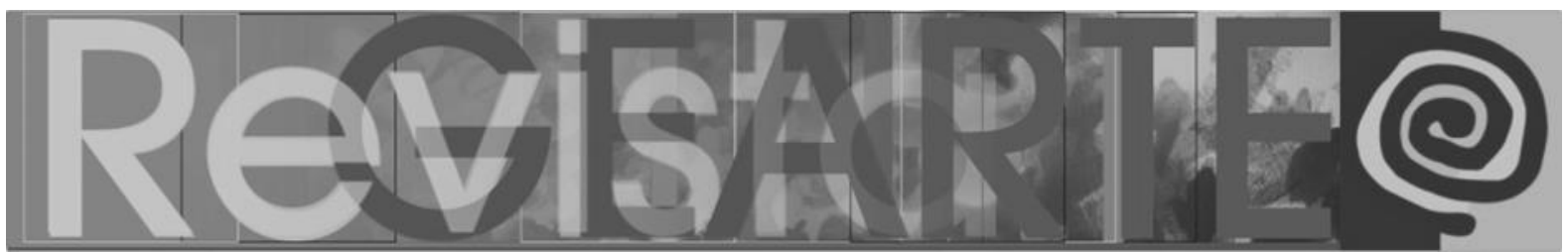

Figuras 10 a 13 - Processo de construção da veste da representante do país imaginário e registro da representante trajada. Autora Nayara da Silva Freitas de Melo
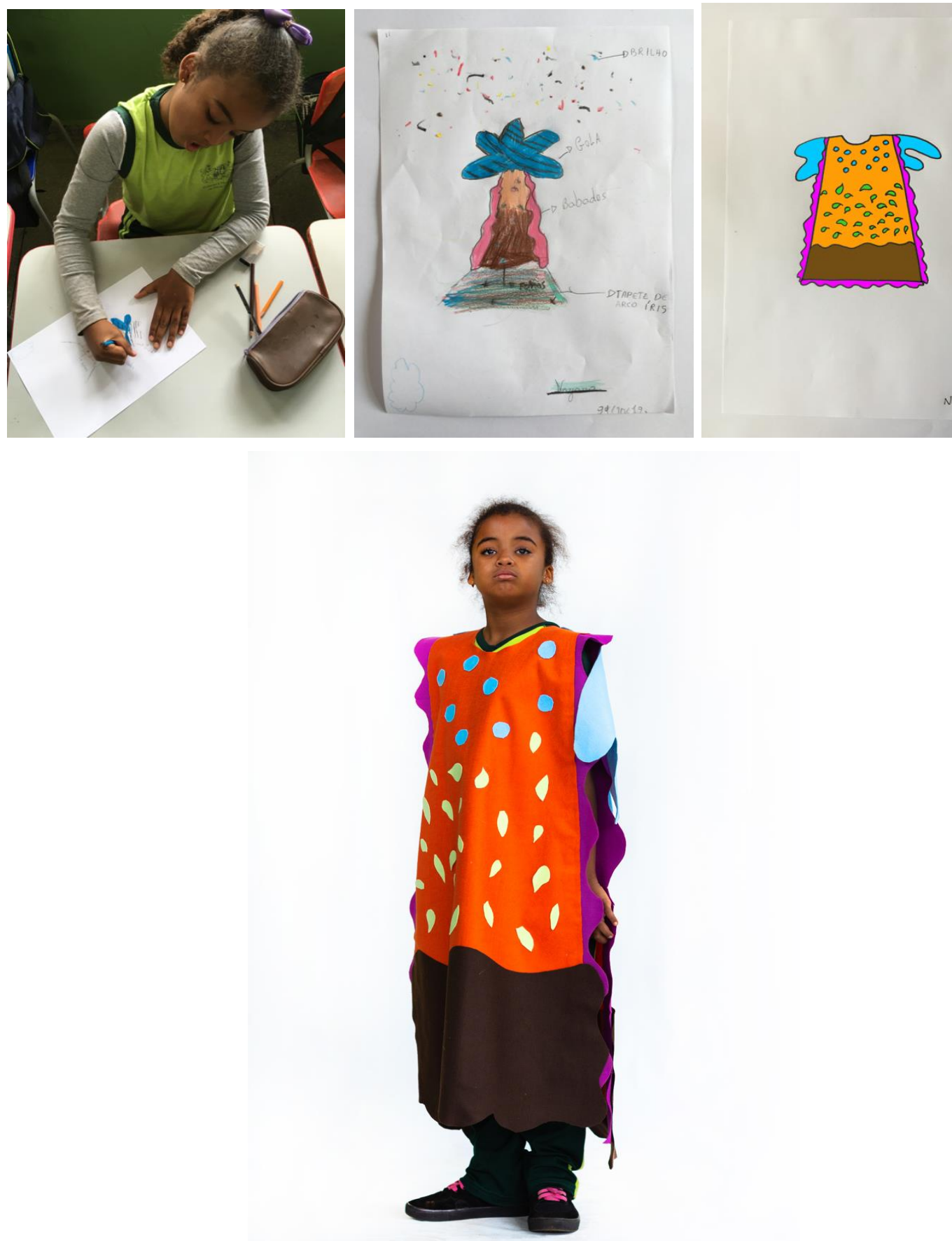

Fonte: Acervo de Gustavo Torrezan (2019).

Foi uma espécie de experimentação conjunta de um intervalo expressa, por exemplo, na ausência de um uniforme, na ação de um outro modo de caminhar, dançar e experimentar o corpo na escola. A sinergia de intenções só aumentava, 


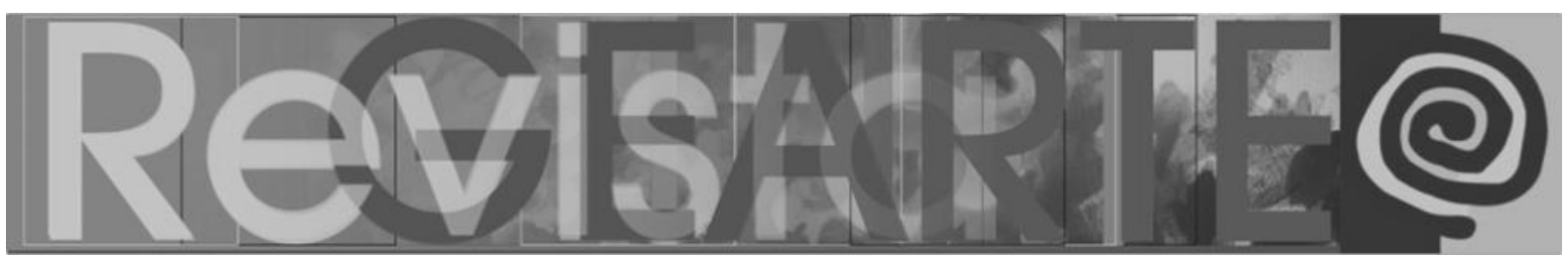

assim como o desejo de estar na sala de aula com os estudantes e o desejo dos estudantes de estarem comigo. Havia instaurado uma cumplicidade propositiva. Ao invés de rejeições, como é comum em ambientes marcados pela rotina, o que se ouvia era a afirmação de querer mais variação, mais experiência.

Uma outra pergunta foi Que vozes podemos convocar? e, com ela, a possibilidade de inventar uma voz para dizer sobre o inaudito, para falar aquilo que nunca se fala, para experimentar um som novo ou um outro modo de dizer que talvez desse sopro, fôlego para continuar uma luta talvez invisibilizada; uma voz como companhia no diálogo sobre tantos assuntos e interesses que não cabem na escola, nos dias, nas famílias. Muitas vezes até cabem, mas, por vezes, são silenciados de tal modo que é preciso criar outras formas de dizer, pôr no mundo por outras vias, abrindo situações de lutas desse falante consigo mesmo ou com sua "memória-mundo". Abrir situações de luta é um modo de se colocar ativo no mundo, construindo com ele, pois, como nos lembra Amador Fernández-Savater (2018, s/p),

\begin{abstract}
Não se abre uma situação de luta porque se sabe, mas, precisamente, para saber. Não se cria uma situação de luta porque tomamos consciência ou finalmente abrimos os olhos, mas para pensar e abrir os olhos em companhia. A luta é uma aprendizagem, uma transformação da atenção, da percepção e da sensibilidade. $O$ mais intenso, o mais potente.
\end{abstract}

E, sem dúvidas, aqueles estudantes do terceiro ano são lutadores por persistir e diante de tantos obstáculos colocados, e os encontros buscavam fomentar momentos de luta, especialmente das lutas de vida que fogem dos clichês pré-estabelecidos de produzir vida pelo consumo e para o consumismo.

Uma outra pergunta geradora foi o que diz nossas músicas e que tipo de sonoridades criamos? A pergunta dava voz ao balbucio, a outras sonoridades que mixam, ampliam, invertem expandem as sonoridades existentes, mas, sobretudo, criam sopros de vida, suspiros, movimentos no ar, que levam consigo nossos corpos, cânticos-desejos. Nesse encontro, os estudantes criaram partituras e experimentaram novas vocalidades, novas músicas, mas essas experimentações, infelizmente, não 


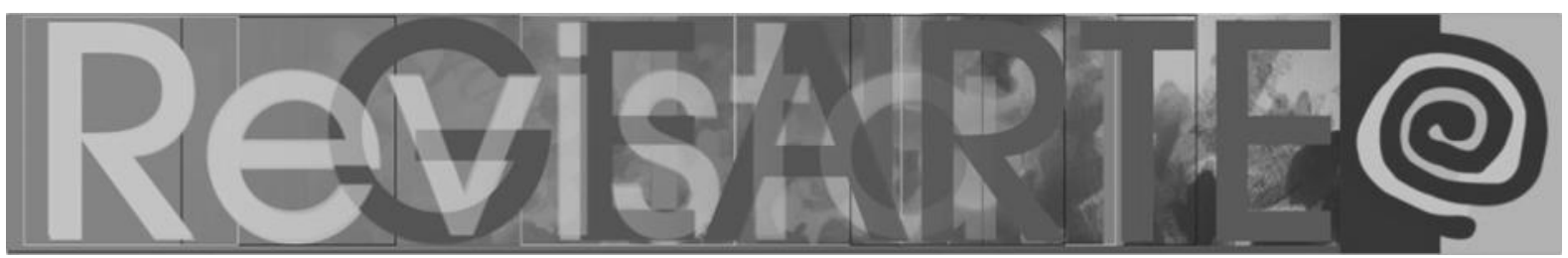

foram registradas, tamanha a agitação durante a experimentação. Porém, no ano seguinte, produzi junto com a musicista Inês Terra o álbum Países Imaginários, que consiste na interpretação dessas partituras ${ }^{4}$. $\mathrm{O}$ álbum gravado foi disponibilizado na internet e compartilhado com os estudantes.

Figura 14 - Letra de música do país imaginário. Autora Nayara da Silva Freitas de Melo

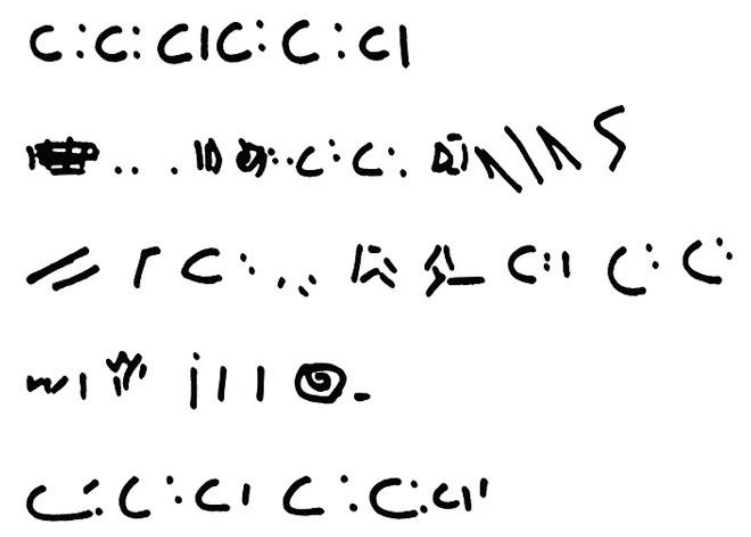

Fonte: Acervo de Gustavo Torrezan (2019).

Com o passar dos dias, na construção do trabalho e nos encontros, pouco a pouco os papéis foram se misturando e os próprios estudantes passaram a ser propositores de perguntas e do que faltava para ser inventado em cada país, sugerindo o que seria gerador do próximo encontro. Também iam avançando a partir do que era proposto, gerando aprofundamento nas reflexões que, por vezes, atravessavam as aulas da professora Márcia e seus conteúdos curriculares. Não foram poucas as vezes em que os estudantes perguntavam que tipo de idioma, número ou relação poderiam utilizar durante as atividades da professora, em uma clara alusão à percepção da exploração da linguagem implicada na proposta da convenção.

Com a complexidade aumentando a partir dos vínculos e confiança maiores, os encontros se deram a partir das perguntas quais discursos reivindicamos? $E$ quais bandeiras colocamos como nossas? e se desdobraram na invenção da bandeira de luta ou de representatividade de cada país imaginário ou do ser que 


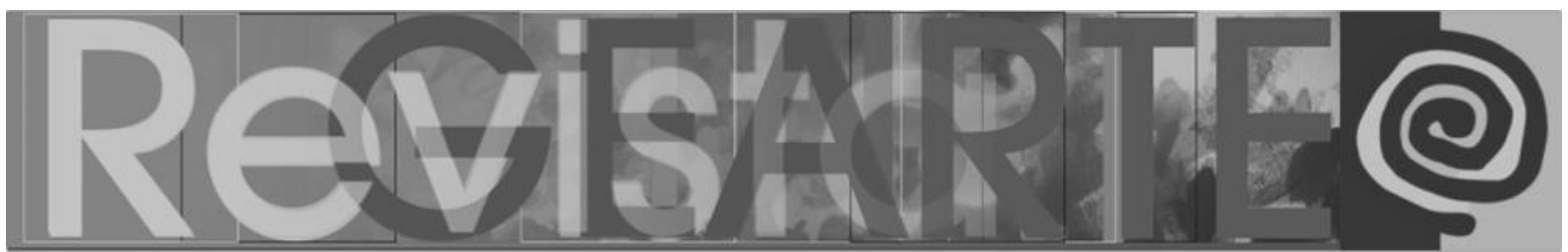

nele habita e dos discursos que se precisa construir para defender algo que se deseja para si e para os seus.

Figuras 15 a 18 - Processo de criação da bandeira de luta do país imaginário. Autora Thainá Vitoria Martins da Cruz
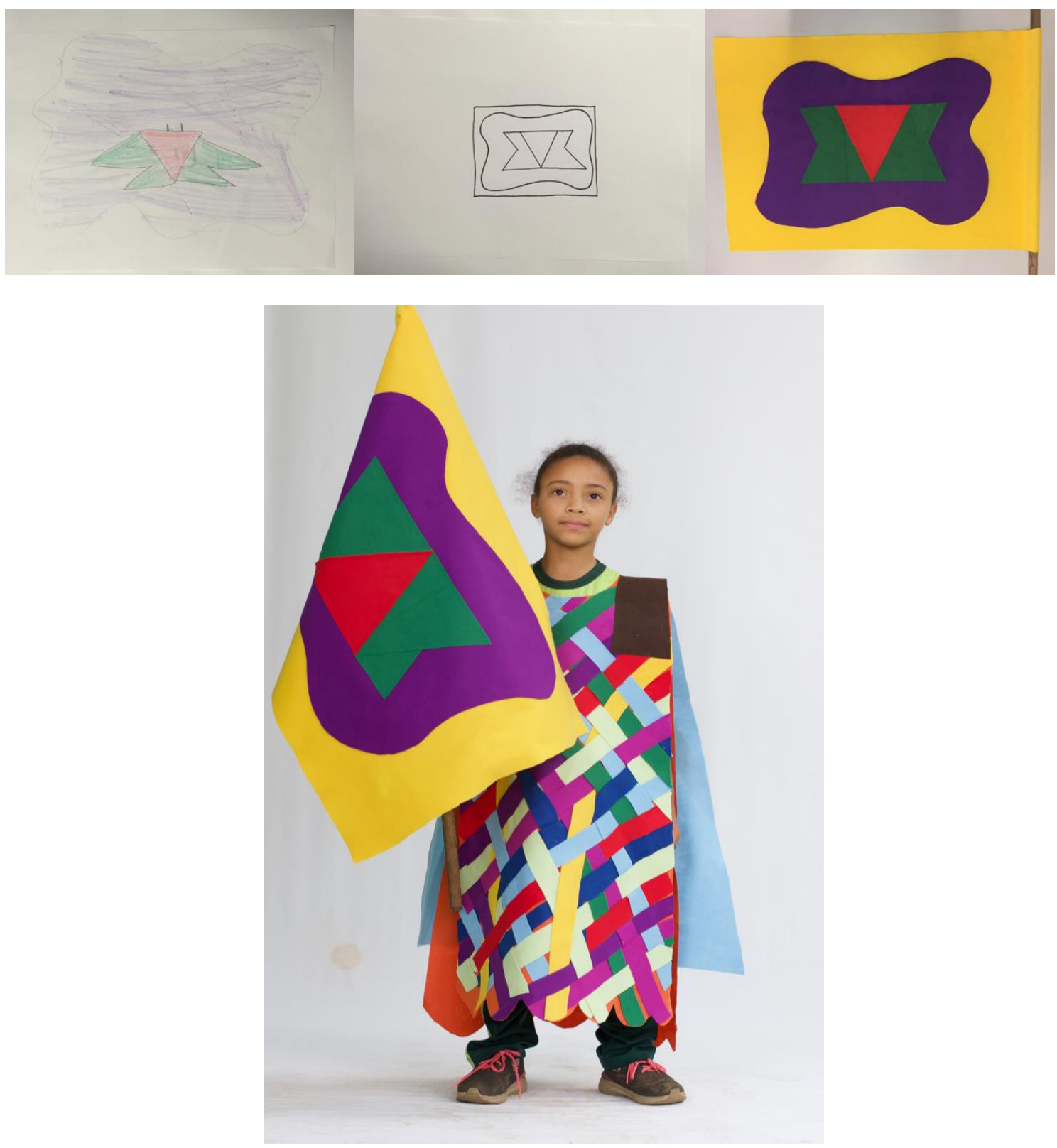

Fonte: Acervo de Gustavo Torrezan (2019).

Produzir uma bandeira é produzir um discurso que enseja ampliar o que é reivindicado ou comum por pares; é também, por intenção ou por pulsão, uma 


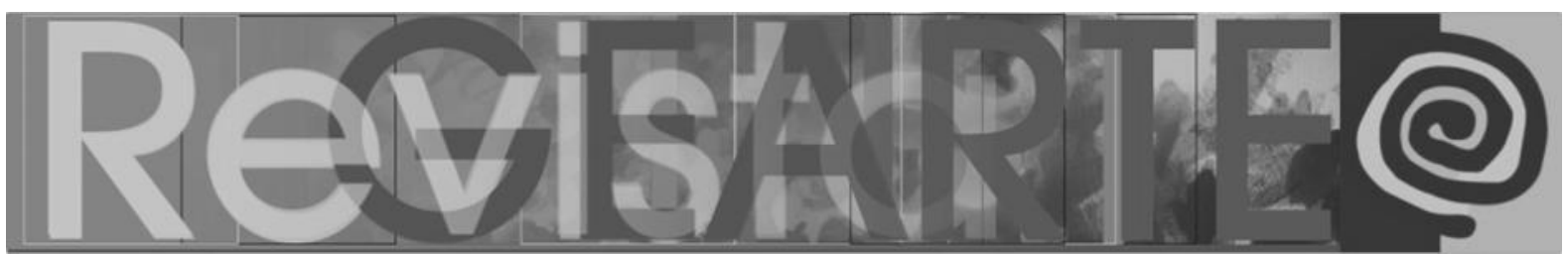

sociabilidade do sul (global), pensada a partir de Amador Fernández-Savater (2017, s/p),

\begin{abstract}
Em que consiste essa sociabilidade do Sul? Em primeiro lugar, é um impulso vital, não-racional. Uma vontade de viver, um querer viver. Mas não viver de qualquer modo, e sim afirmando um tipo de vínculo, um tipo de existência, uma certa ideia de felicidade: um estar-juntos antropológico. É também um conjunto de saberes e estratégias para reproduzir esses vínculos, essas formas de vida. (...) A insurreição da sociabilidade do Sul [consiste em levantar outras bandeiras que não são as mesmas daquelas dos que chamamos de norte global $]^{5}$ e consistiria em afirmar politicamente esta outra ideia de felicidade, esta potência subterrânea, estas vagas oceânicas.
\end{abstract}

São tantas as bandeiras que colocam como nossa e como nossa identidade, que criar uma nova bandeira, talvez, fosse a possibilidade de inventar uma nova luta que pouco ou nada diz respeito a essas existentes, ou então de fazer bandeiras capazes de abarcar atravessamentos das lutas existentes para criar novas possibilidades de lutar.

Ainda se deram encontros a partir das perguntas com quem convivemos? Como multiplicamos nossos ecossistemas? O que é justiça? Pelo que devo lutar? O que cabe no meu sonho? e muitas outas para, então, inventarmos e multiplicarmos os seres viventes e não viventes - os seres existentes nos ecossistemas de cada imaginação, de cada país. Pensar em ecossistemas, partindo dos países imaginários até chegar à sala e à aula como a configuração de um ecossistema circunstancial, que pode ser inventando de outro modo, mudando perspectivas, mostrou-se como oportunidade para tirar a centralidade humana das coisas, do mundo. 


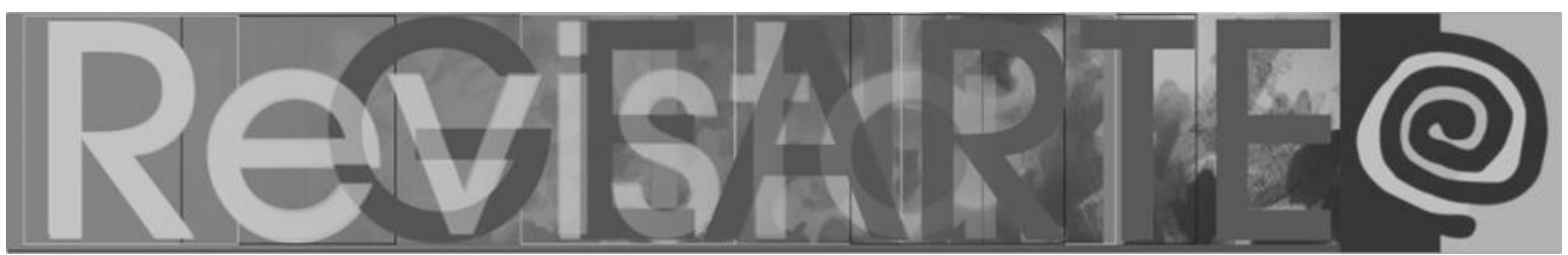

Figura 19 - Plantas e animais dos países imaginários. Autora Nayara da Silva Freitas de Melo

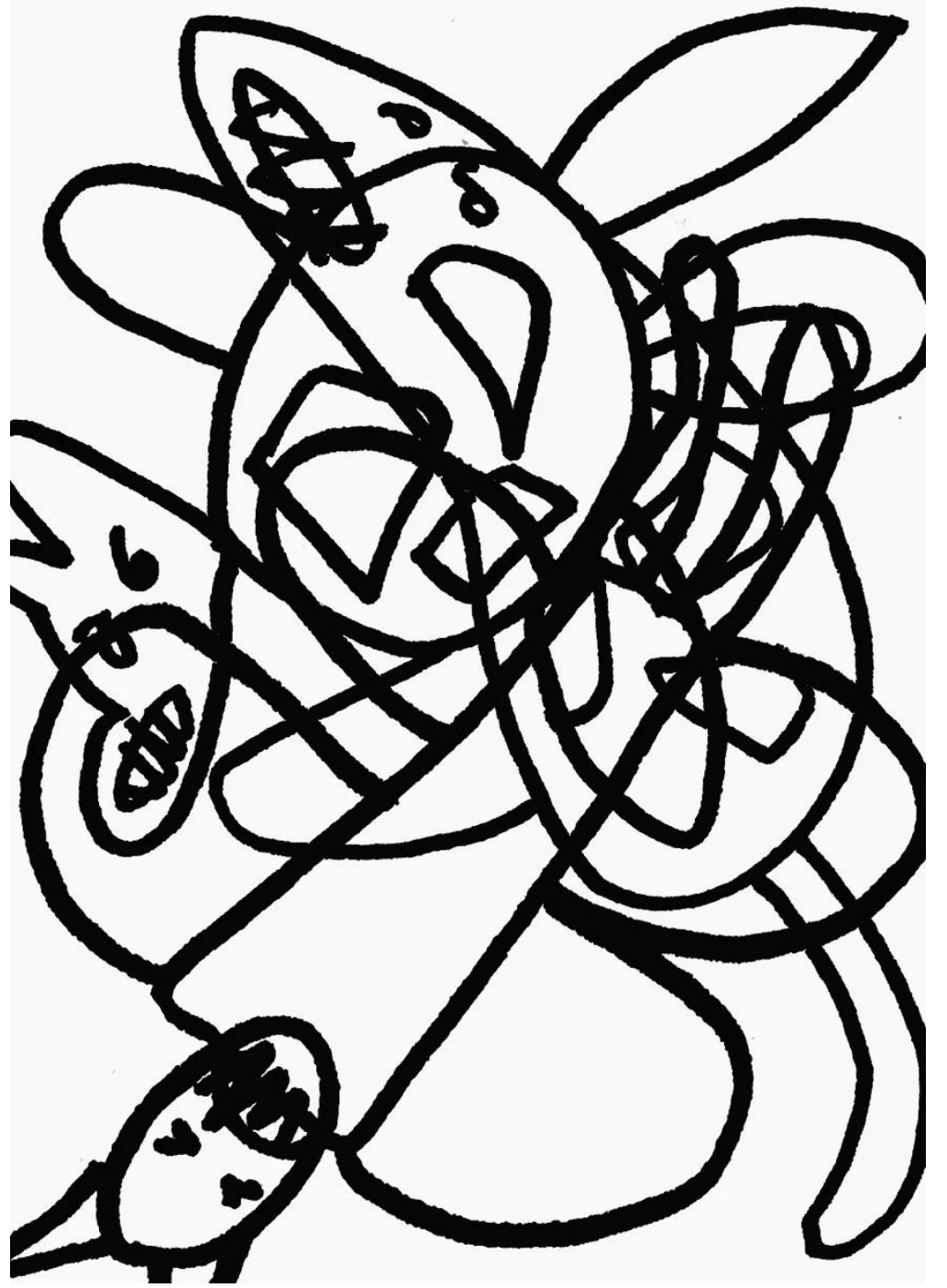

Fonte: Acervo de Gustavo Torrezan (2019).

Especialmente, é a oportunidade de entender a aula como um acontecimento de seres e de diferentes corpos, como nos convida a pensar Henrique Parra (2017, s/p):

Por isso a importância de reaprendermos a ativar a capacidade do encontro, de estar e permanecer juntos, de criar um ambiente com sua[s] cultura[s], suas infraestruturas, seus códigos e sua economia, para que sejamos capazes de dar sustentação no tempo às práticas e valores que desejamos reverberar. 


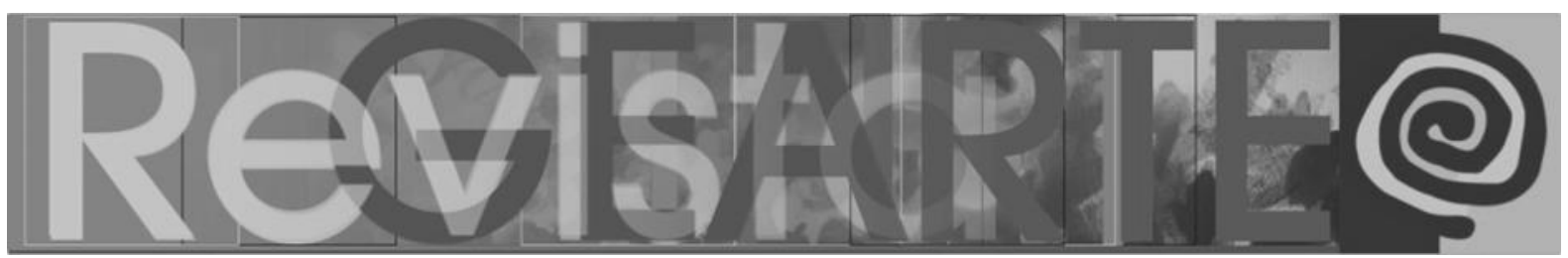

Trata-se de habitar a diferença e fomentar a multiplicidade a partir do experimentar a criação de ecossistemas que valorizem a proliferação de vida, mas sem perder o lastro com o território.

Cada uma dessas pequenas partes disparadas por perguntas em encontros-acontencimentos compõem o projeto e se colocam como material para edificar um campo, que é o da criação enquanto processo singular de construção de conhecimento e de educação na diferença, tomada a partir e de dentro da prática artística.

\section{Alegre tumulto}

Após a realização dos encontros a partir das perguntas geradoras e com o exercitar, o laboratiratorializar, fomos juntos, pouco a pouco, produzindo uma espécie de tumultuo bom, que é uma política de cuidarmos uns dos outros (e digo outros em um sentido muito ampliado, envolvendo vários seres que não são só os humanos, ou seja, uma população não só humana) fazendo festa e criando badernas, que são incessantes rearranjos que não se estagnam em formas prontas, definidas, aprisionantes.

Com cada passo do processo, criamos um experimento imaginativo, que é cada país, e um festejo celebrativo, que é a reunião desses diferentes países. Essa reunião optei por chamar de convenção, ainda que não desejasse convencer ou convencionar nada, o nome foi utilizado por remeter ao imaginário das reuniões globais nas quais os presidentes dos países acordam diretrizes comuns. Os estudantes puderam habitar o dissenso culminando no composto que é a $1^{\underline{a}}$ Convenção Mundial dos Países Imaginários, realizada no parquinho da Escola Benvinda - um processo educativo que coloca a convivialidade como mote para o aprendizado tal como propõem Ivan Illich (GAJARDO, 2010).

Nessa perspectiva de convivência, o trabalho se fez como uma prática de educação em aulas que se produziram como encontros, acontecimentos, que engendram experimentos de retomar a ideia de formas de vida para a superação 


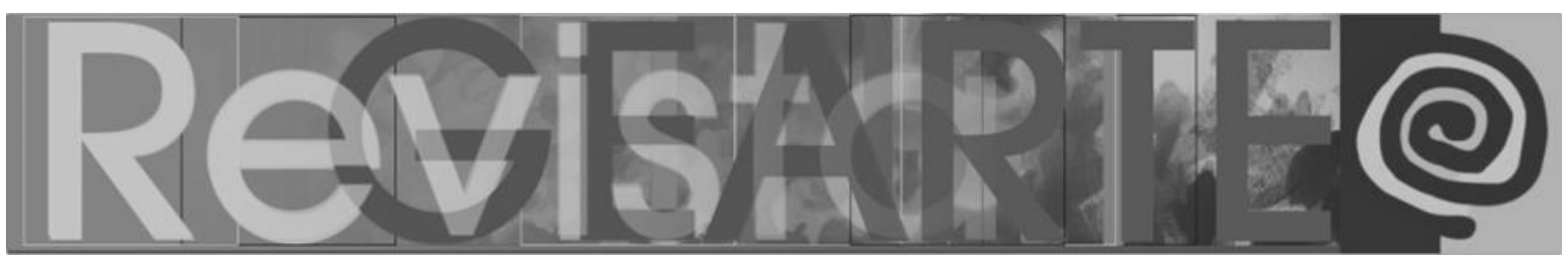

da melancolia que, por vezes, deixa-nos estagnados ou prostrados diante do mundo. Nessa prática, compreendo que não existe um "outro mundo para se construir", mas que existem outras relações para se construir, outros arranjos que vamos produzir nesse mesmo mundo, outros modos de vida (MORAES, 2017).

Figura 20 - Registro da 1ª Convenção Mundial dos Países imaginários

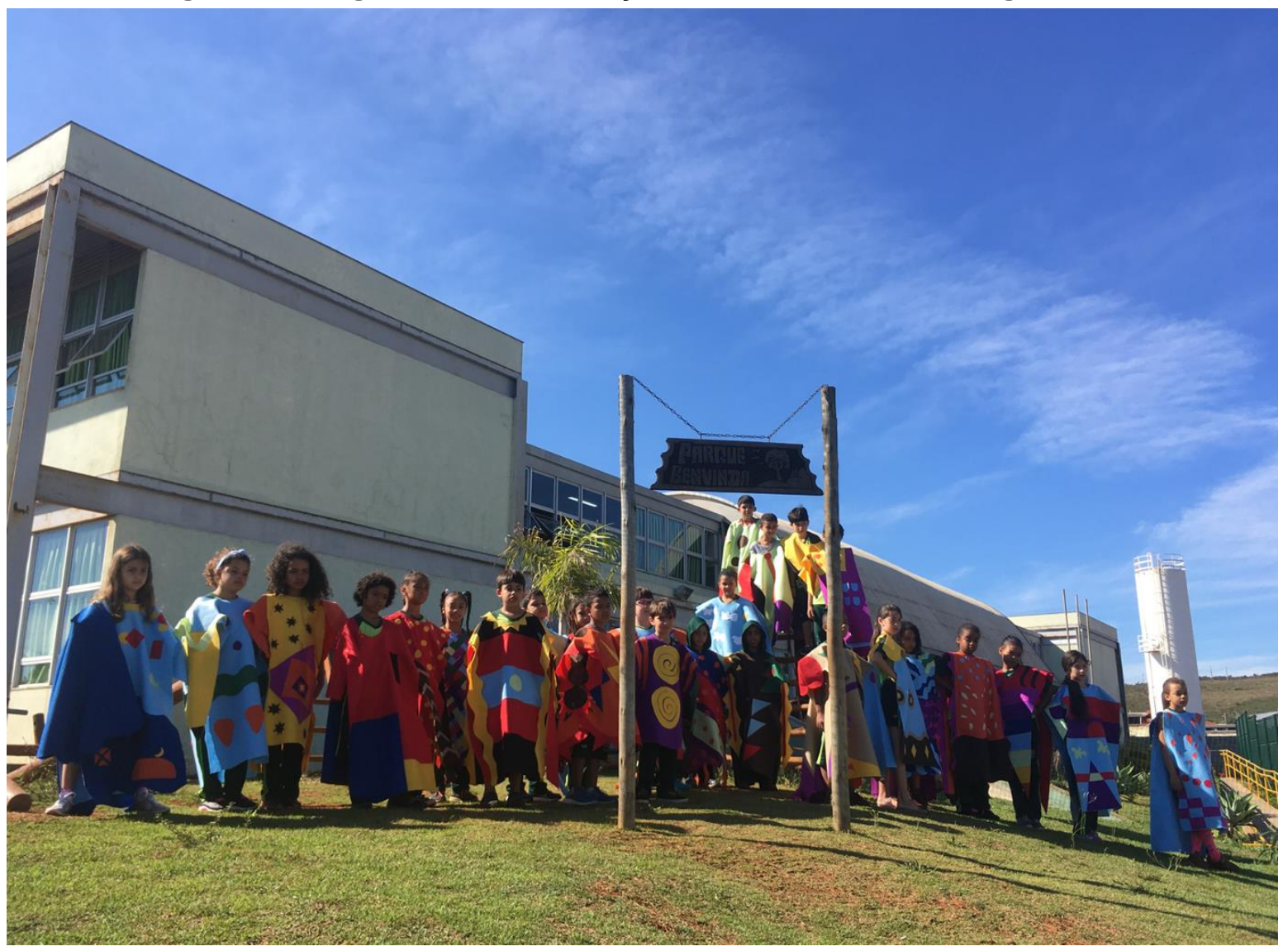

Fonte: Acervo de Gustavo Torrezan (2019).

Então, com a Convenção Mundial dos Países Imaginários, busquei produzir um fabular. Um fabular que se dá como movimento de afirmação da criação, através de um corpo de sensações, como criação do meio que traça as linhas nas quais tudo se torna possível movimentos de forças que não começam e nem terminam nelas próprias e, por isso, não ficam na chave dialética entre a utopia e a distopia, mas se ocupam de agenciar esse intervalar comentado no início deste artigo. 


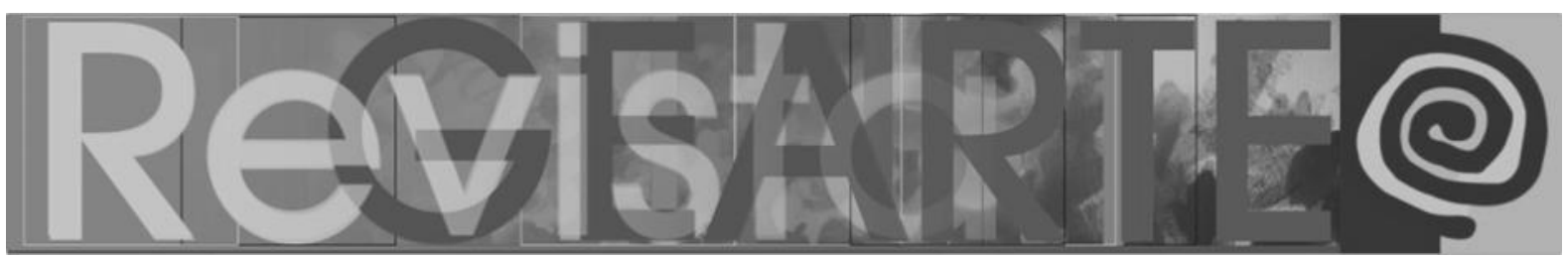

A fabulação é uma possibilidade de pensar a arte e a torção da linguagem no devir incessante que cria um plano de expressão movimentando forças e gerando excessos de possibilidades face às impossibilidades, sendo capaz, também, de produzir o real, e não só de corresponder a ele como resposta pronta, esperada, determinada, já que fabular é abarcar o entre das forças criadoras, como nos convida a pensar Ester Maria Dreher Heuser (2009, p.51) quando coloca que é preciso:

[...] afirmar a necessidade da produção da fabulação também na educação, por estudantes e professores, para que saiamos da condição de sujeitos conhecedores, alienados de [nossa] potência criativa e passemos a sujeitos criadores que utilizam sua força sobre si.

Depois da convenção ter acontecido no parquinho da escola, os representantes dos países imaginários seguiram para o pátio lá fazendo festa, e, tendo a alegria como força revolucionária (LINS, 2009), celebraram a produção de histórias e narrativas que reúnem complexidades ao mesmo tempo em que conseguem manter as bordas abertas para novas conexões, receptividades, arranjos, conexões e outras novas invenções (HARAWAY, 2016).

\section{Habitar o dissenso}

O que produzimos nos dias, nos encontros na sala do terceiro ano da Escola Benvinda foram exercícios que, um a um, pouco a pouco, foram cultivando a imaginação e, com ela, a criação de cada país imaginário e, ao final, a criação da convenção mundial. No percurso realizado, nos encontros-acontecimento com os alunos, pudemos sempre habitar o dissenso que, ao contrário do que se tem propagado costumeiramente, significa o convívio das diferenças, em que cada singularidade se expressa em relação ao conjunto; multiplicidade como um conjunto das diferenças. Os estudantes puderam decidir juntos o futuro do planeta, ou melhor dizendo, puderam re-criar sua própria terra e experimentar na escola um processo educativo de imaginação política. 


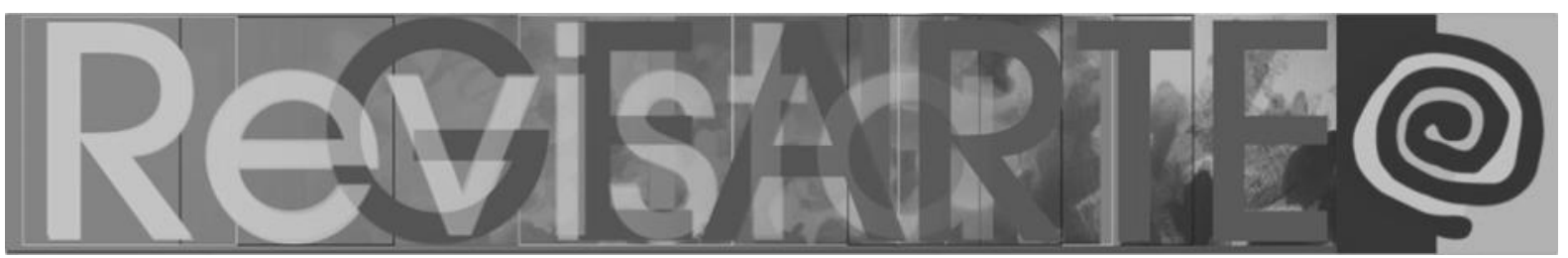

Figura 21 - Celebração com os representantes após a Convenção Mundial dos Países Imaginários

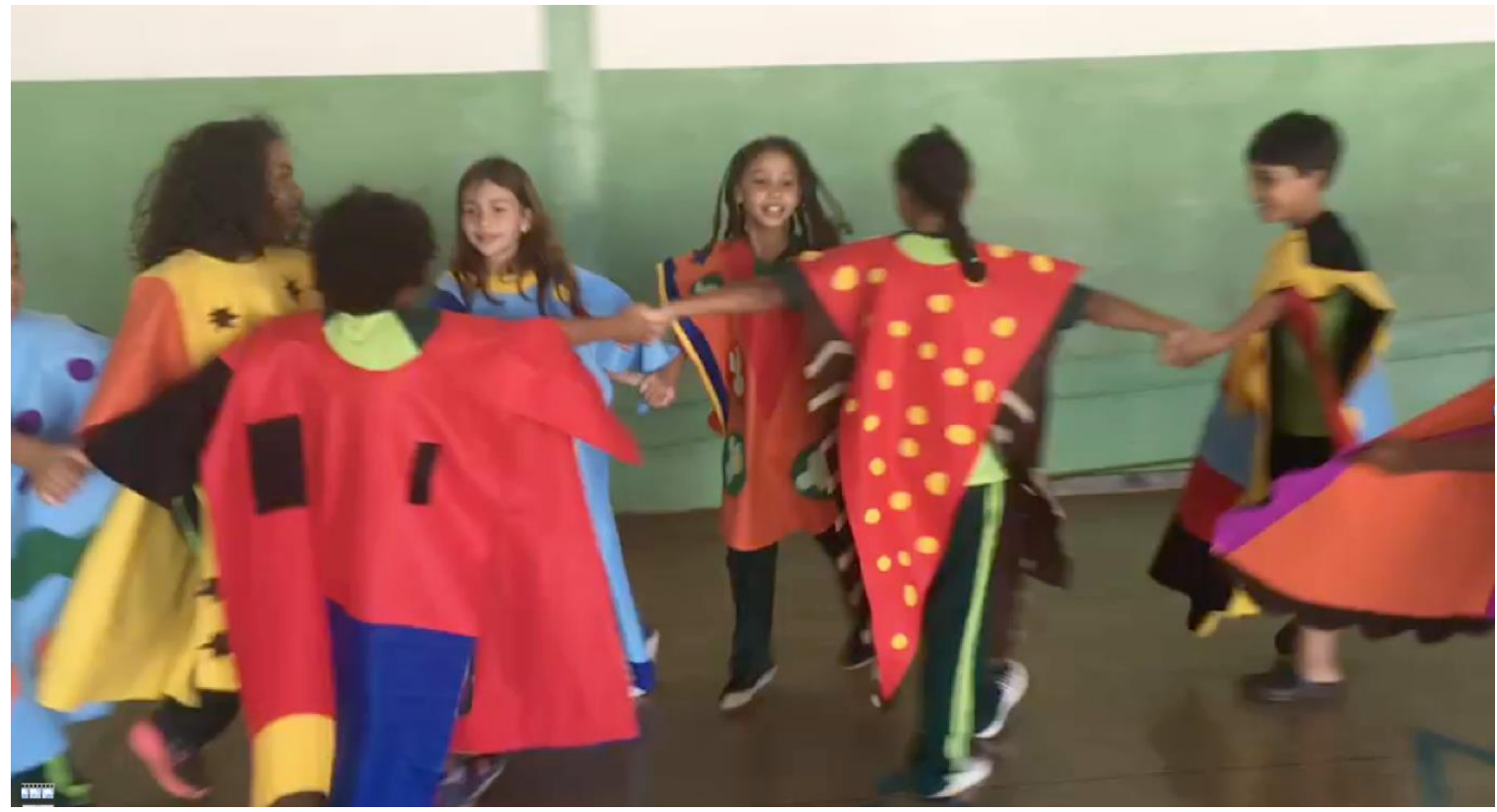

Fonte: Acervo de Gustavo Torrezan (2019).

Nesse sentido, refiro-me à filósofa brasileira Denise Ferreira da Silva (2016) quando indica a importância da diferença sem separabilidade, fugindo das práxis modernas que produzem a sociabilidade como operação de um programa éticopolítico que origina violência àqueles que estão do "[...] 'outro' lado (cultural) da humanidade". Apostar na diferença sem separabilidade, a partir do dissenso, é cultivar a possibilidade de libertar "[...] o pensamento das amarras da certeza e [abraçar] o poder da imaginação para criar" (FERREIRA DA SILVA, 2016, p. 58) e, com isso, imaginar, inventar novos possíveis já que esses que temos diante de nós, desse mundo tal qual o conhecemos, está fadado ao fracasso.

A filósofa nos convida a pensar o mundo como "[...] uma plenitude, uma composição infinita em que cada singularidade existente está sujeita a se tornar uma expressão possível de todos os outros existentes, com os quais ela está emaranhada para além do espaço e do tempo" ( FERREIRA DA SILVA, 2016, p.60 ) que seja capaz de valorizar as diferenças ao criar conexões, emaranhados, uma trama disforme que faz habitar e correlacionar as diferenças em um mesmo espaço e tempo, compondo forças que expressam diferentes formas de vida. 


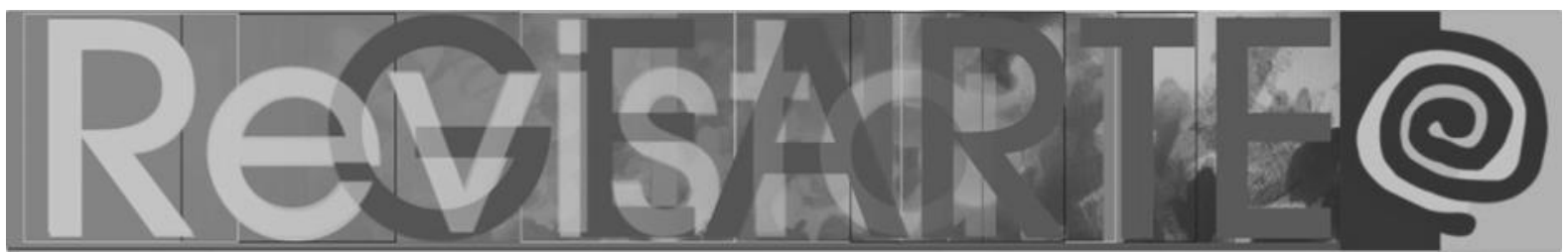

A realização do trabalho Convenção Mundial dos Países Imaginários, na Escola Benvinda, durante a residência artística no Ja.Ca, e em meio às adversidades daquele contexto, foi para mim a criação de um emaranhado de conexões que potencializam as diferenças, fazendo com que elas coabitem o mesmo espaço e tempo, originando, em outras palavras, uma expressão de vitalidade na qual "[...] ser um é sempre tornar-se com muitos" (HARAWAY, 2008, p.12), o que se faz com alegria e resistência e que, através da imaginação, cuida e fomenta nossa subjetividade tal qual indica Krenak (2019, p. 33):

[...] se existe uma ânsia por consumir a natureza, existe também uma por consumir a subjetividade - as nossas subjetividades. Então vivê-las com liberdade que formos capazes de inventar, não botar ela no mercado. Já que a natureza está sendo assaltada de uma maneira tão indefensável vamos, pelo menos, ser capazes de manter nossas subjetividades, nossas visões, nossas poéticas sobre a existência. Definitivamente não somos iguais, e é maravilhoso saber que cada um de nós que está aqui é diferente do outro, como constelações. O fato de podermos compartilhar esse espaço, de estarmos juntos viajando não significa que somos iguais; significa exatamente que somos capazes de atrair uns aos outros pelas nossas diferenças, que deveriam guiar nosso roteiro de vida. Ter diversidade, não isso de uma humanidade com o mesmo protocolo. Porque isso até agora foi só uma maneira de homogeneizar e tirar nossa alegria de estar vivos.

\section{Notas}

1 Sobre a Brincadeira, referencio Despret (2007) "Se há algo que a brincadeira faz é justamente mudar as significações, romper com o literal. A brincadeira é o paraíso da homonímia: um gesto que, em outros contextos, traduz medo, agressão, relação de forças, se rearranja, se desfaz e se refaz de outro modo. A brincadeira é o lugar da invenção e da criatividade, o lugar da metamorfose do mesmo em outro, tanto para os seres quanto para as significações. Ela é o lugar mesmo do imprevisível, mas sempre segundo regras que conduzem esta criatividade e seus ajustamentos" (Tradução minha).

2 Escrito do autor.

3 Escrito do autor.

4 O álbum está disponível na plataforma You Tube https://www.youtube.com/watch?v=elMPf76ipqw

5 Escrito do autor.

\section{Referências}

AMORIM, Antonio Carlos. Conversas in-finitas: mudanças climáticas, divulgação científica, educação e.... Disponível em http://climacom.mudancasclimaticas.net.br/conversas-infinitas/?fbcl id=IwAR0QY2GRMgXf07RtqgDBxiTd7JaExZI1A75eWZd-SLBStWdPk7f2O2sdw2A. Acesso em 24.02.2021. 


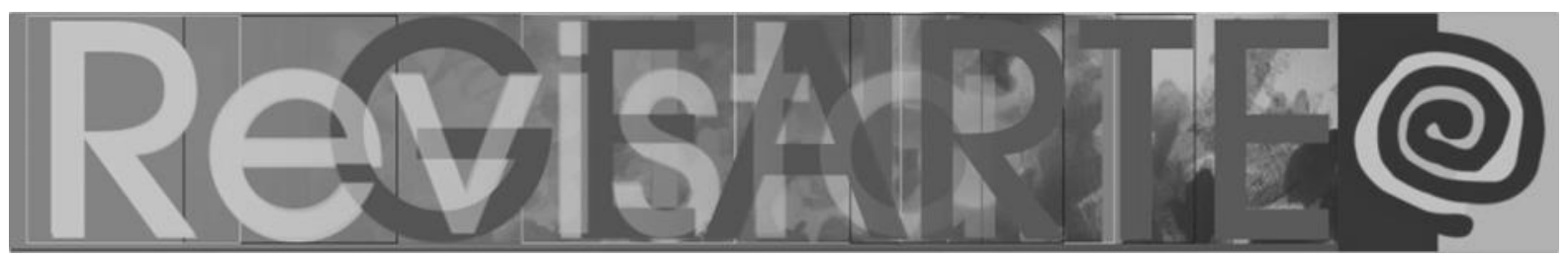

DELEUZE, Gilles. Conversações. SP: Editora 34, 2013.

DESPRET, Vinciane; PORCHER, Jocelyne. Etre Bête. Arles: Actes Sud, 2007.

FERNÁNDEZ-SAVATER, Amador. Pensar: uma necessidade contemporânea. Disponível em https://urucum.milharal.org/2018/09/23/pensar-uma-necessidade-contemporanea/. Acesso em 18 de fevereiro de 2021.

FERNÁNDEZ-SAVATER, Amador. Pós Capitalismo a dimensão sensível. Disponível em https://outraspalavras.net/pos-capitalismo/pos-capitalismo-a-dimensao-sensivel/ acesso em $18 \mathrm{de}$ fevereiro de 2021.

FERREIRA DA DILVA, Denise. Catálogo da 32 Bienal de São Paulo. Disponível em http://www.bienal.org.br/publicacoes/8077 acesso em 20.02.2021.

GAJARDO, Marcela. Ivan Illich / Marcela Gajardo. Trad e org. José Eustáquio Romão. Recife: Fundação Joaquim Nabuco, Editora Massangana, 2010.

HARAWAY, Donna J. When species meet. Minneapolis: University of Minnesota Press, 2008.

HARAWAY, Donna. Staying with the Trouble: Making Kin in the Chthulucene. Durham and London: Duke University Press. 2016.

HEUSER, Ester Maria Dreher. Fábula da existência seguida de notas sobre a fabulação. In.: CORAZZA, Sandra Mara. Fantasias de escritura - filosofia, educação, literatura. Porto Alegre: Sulina, 2010.

KRENAK. Ailton. Ideias para adiar o fim do mundo. São Paulo: Companhia das letras, 2019.

LAFUENTE, Antonio. Educação: a aposta radical do oficinar. Disponível em https://outraspalavras .net/descolonizacoes/educacao-a-aposta-radical-do-oficinar/. Acesso em 03.03.2021.

LINS, Daniel. Alegria como força revolucionária, ética e estética dos afetos. Disponível em https://www.youtube.com/watch?v=IK0FzHqHpf8. Acesso em 23.02.2021.

MORAES, Alana. Não existe 'outro mundo para se construir'. Existem outras relações e modos de vida a se construir nesse mesmo mundo: Entrevista especial com Alana. Disponível em http://www.ihu.unisinos.br/159-noticias/entrevistas/572943-nao-existe-outro-mundo-para-seconstruir-existem-outras-relacoes-e-modos-de-vida-a-se-construir-nesse-mesmo-mundoentrevista-especial-com-alana-moraes. Acesso em 18.02.2021.

SALOMÃO, Waly. Hélio Oiticica: Qual é o parangolé? E outros escritos. São Paulo: Companhia das letras, 1996.

SAMAIN, Etienne. As "Mnemosyne(s)" de Aby Warburg: Entre Antropologia, Imagens e Arte. Revista Poiésis, n 17, Jul. de 2011. Disponível em http://periodicos.uff.br/poiesis/article/d ownload/27032/15733 Acesso em 16.02.2021.

TIQQUN. "Como fazer".... Disponível em https://issuu.com/n-1publications/docs/cordel_tiqqun. Acesso em 02.03.2021.

\section{Gustavo Torrezan}

É artista, pesquisador, educador. Pós-dourando pela PUC- SP, Doutor em poéticas visuais, mestre em educação e bacharel em artes visuais pela Unicamp. É pesquisador no Centro de Pesquisa e Formação do Sesc. Em sua prática artística, volta-se a refletir sobre as estruturas de poder que configuram historicamente as organizações coletivas, bem como suas constituições culturais e identitárias. Realiza trabalhos híbridos para discutir as relações de domínio, a partir das quais se modulam os processos de subjetivação da sociedade. Nesse processo, evoca os campos da sociologia e da 


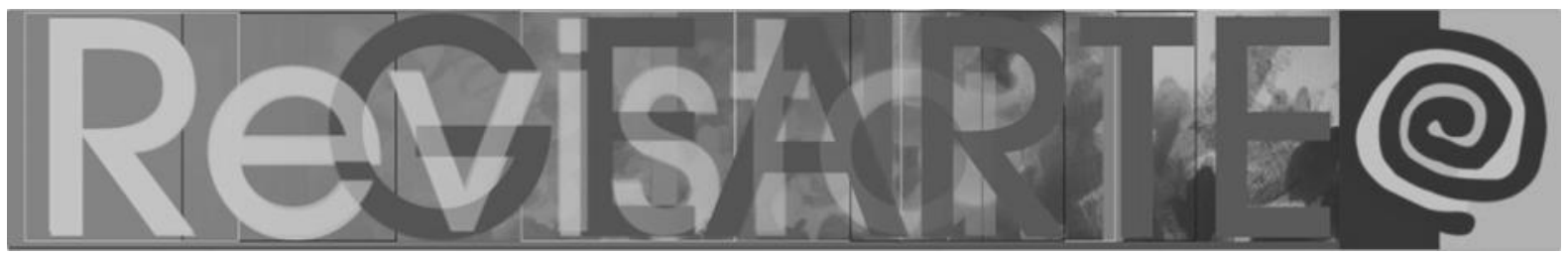

geopolítica. Seus trabalhos insurgem de circunstâncias comunitárias específicas. Nesse sentido, as noções de colaboração e de dialogia também vêm sendo exercitadas em sua produção.

ORCID: https://orcid.org/0000-0002-3995-8465

E-mail: ghtorrezan@gmail.com

Currículo: http://lattes.c npq.br/00772 95633943448

Recebido em 2 de junho de 2021

Aceito em 4 de agosto de 2021 